\title{
Evasão escolar no âmbito do Instituto Federal de Brasília
}

\author{
School evasion of the Federal Institute of Brasília scope
}

Sheyla Villar Fredenhagem - Instituto Federal de Brasília - sheyla.fredenhagem@ifb.edu.br

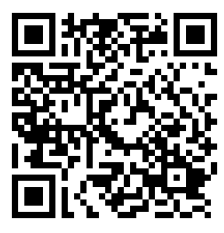

Resumo: Este artigo trata de uma investigação, apoiada nos pressupostos da pesquisa qualitativa e da Fenomenologia, sobre as causas da evasão de alunos de cursos dos níveis técnico, tecnológico e de licenciatura do Instituto Federal de Brasília. O objetivo da pesquisa é fornecer subsídios, como instrumentos de meta-avaliação, que orientem intervenções que se façam necessárias na Instituição, em favor da permanência e do êxito dos educandos. Foram observados os cursos técnicos em Logística, Agronegócio, Cooperativismo, Eventos, Informática, Serviços Públicos, Agroindústria, Agropecuária, Reciclagem, Comércio, Manutenção e Suporte em Informática - recorte compreendido entre 01/2009 e 12/2012. Foram pesquisados cursos superiores de Licenciatura em Dança, período de 08/2010 a 12/2014; Tecnologia em Gestão Pública, período de 08/2012 a 07/2015; Licenciatura em Química, período de 03/2012 a 12/2015; e Tecnologia em Agroecologia, período de 02/2011 a 12/2013. Há cursos em andamento. Foram registrados $59,63 \%$ de evasão no curso superior e $55,35 \%$ no técnico. Nesse recorte, obteve-se um total de $56,35 \%$ de evasão, mediante atualização de dados, realizada em 05/2014, sob a ótica do índice de perda. Ouvidos 218 alunos, é possível inferir que as falas constituem indicadores seguros relativos aos campos pedagógico, administrativo, de ingresso, curricular e a outros de cunho organizacional e social. Observada, localmente, a evasão de cada campus do IFB, em tempo real, visando reverter a decisão do aluno de evadir-se, propõe-se a formação de grupos de estudo compostos pelos segmentos docente e técnico, a fim de que operem intervenções locais, sob programas de capacitação elaborados mediante esses indicadores.

Palavras-chave: causas centrais e subjacentes, indicadores, meta-avaliação institucional.

Abstract: This article was written about an investigation, supported in the assumptions of qualitative research and Phenomenology, about the causes of evasion of students in technical, technological and higher education levels of Federal Institute of Brasilia. The purpose of this research is to provide subsidies, as meta-evaluation instruments, to conduct necessary interventions in the institution, in favor of permanence and success of students. The observed technical courses were Logistics, Agribusiness, Cooperative Movement, Events, Computers, Public Services, Agroindustry, Agriculture, Recycling, Trade, Computer Maintenance and Support - in the period between 01/2009 and 12/2012. The observed graduate courses were Graduation in Dance, period from 08/2010 to 12/2014; Technology in Public Administration, from 13/08/2012 to 20/07/2015; Graduation in Chemistry, period from 03/2012 to 12/2015; and Technology in Agroecology, period from 02/2011 to $12 / 2013$. There are courses in progress. It was recorded an evasion of $59.63 \%$ in upper course and $55.35 \%$ in technical. In this period, there was obtained a total of 56.35\% evasion, through data update, held in 05/2014, from the perspective of the index loss. After heard 218 students, it is possible to infer that speeches are safe indicators relating to educational, administrative, admission and curricular fields and other organizational and social oriented fields. Observed in a local way, the evasion of each campus of the IFB, in real time, seeking to reverse the decision of the student to evade, it is proposed the formation of study groups with teachers and technical segments, intending local interventions that operate under training programs developed taking in these indicators.

Keywords: central and underlying causes, indicators, institutional meta-evaluation. 
O despertamento pela busca in loco de causas possíveis que justifiquem a evasão de alunos de cursos ofertados pelo Instituto Federal de Brasília (IFB) tem seu marco inicial nas discussões realizadas em 2010 - dois anos após a implantação do Instituto Federal de Brasília (Lei n 11.892, de 29 de dezembro de 2008) -, na Pró-Reitoria de Ensino do IFB, a respeito do papel social da Instituição, das políticas de ingresso e das ações em favor da inclusão, principalmente em se tratando de alunos passíveis de vulnerabilidade. Essa reflexão culminou no planejamento de ações batizadas, na época, de pró-permanência, cujo intuito era estabelecer condições que possibilitassem a continuidade e a permanência dos estudantes nos cursos ofertados pela Instituição, favorecendo a terminalidade. Nesse contexto, desde então, partimos para a busca de causas prováveis que justificassem o quadro da evasão, visando levantar indicadores que comprovassem a exclusão, por meio da certificação das causas de abandono de cursos ouvidas do próprio aluno, a fim de que a análise desses dados culminassem em medidas fundamentadas em favor de soluções e/ou de prevenção do desvio. No ano de 2012, foram publicados os primeiros resultados na Revista Eixo v.1, $n^{\circ} 2$, após terem sido ouvidos 282 alunos evadidos, oriundos de cursos variados, notadamente os de Formação Inicial e Continuada. Nesta segunda edição da pesquisa, que teve início no segundo semestre de 2012, ficou acordado com a Pró-Reitoria de Ensino do IFB que seriam observados apenas cursos técnicos e superiores. Quanto à escolha dos cursos, a decisão deveu-se às ofertas existentes, naquele momento, no IFB, ou seja, outros cursos técnicos e superiores ainda não eram ofertados, assim como alguns campi não existiam. Outros, naquele ano já instalados, encontravam-se em processo de estruturação, com ofertas apenas de cursos de formação inicial e continuada. No tocante aos cursos técnicos - Logística, Agronegócio, Cooperativismo, Eventos, Informática, Serviços Públicos, Agroindústria, Agropecuária, Reciclagem, Comércio, Manutenção e Suporte em Informática - pontuou-se o movimento da evasão ocorrido no período compreendido entre 01/2009 e 12/2012. Em relação aos cursos superiores, alguns ainda não concluídos, foram pesquisados cursos de Licenciatura em Dança, compreendendo os períodos de 08/2010 a 12/2014; Licenciatura em Química, referente ao período de 03/2012 a 12/2015; Tecnologia em Gestão Pública, referente ao período de 08/2012 a 07/2015; e Tecnologia em Agroecologia, período de 02/2011 a 12/2013. Estabelecido esse recorte, foram ouvidos 218 alunos, aproximadamente $32,78 \%$, num universo de 665 alunos evadidos (1180 matrículas), conforme listas fornecidas pelo Sistema Nacional de Informações da Educação Profissional e Tecnológica (Sistec/Mec) e/ou pelo Registro Acadêmico de alguns campi, sendo 501 casos (905 matrículas) de evasão referentes aos cursos técnicos, e 164 (275 matrículas) aos superiores, ofertados pelos Campi Brasília, Gama, Planaltina, Samambaia, Taguatinga e Taguatinga Centro. Os 218 alunos participantes da pesquisa foram aqueles que atenderam ao nosso apelo. Trata-se de parcela das listas oriundas do Sistec/Mec e/ou campi, nas quais constava o nome dos alunos evadidos. Foram registrados, nesse recorte, $59,63 \%$ de evasão no curso superior e 55,35\% no técnico. Considerando os dois níveis, obteve-se o total de 56,35\% de evasão. Destacamos que, nesse percentual, considerou-se a atualização de dados de alguns cursos feita em 05/14, sob a ótica do índice de perda.

Gráfico 1 - Percentual de evasão nos cursos superiores.

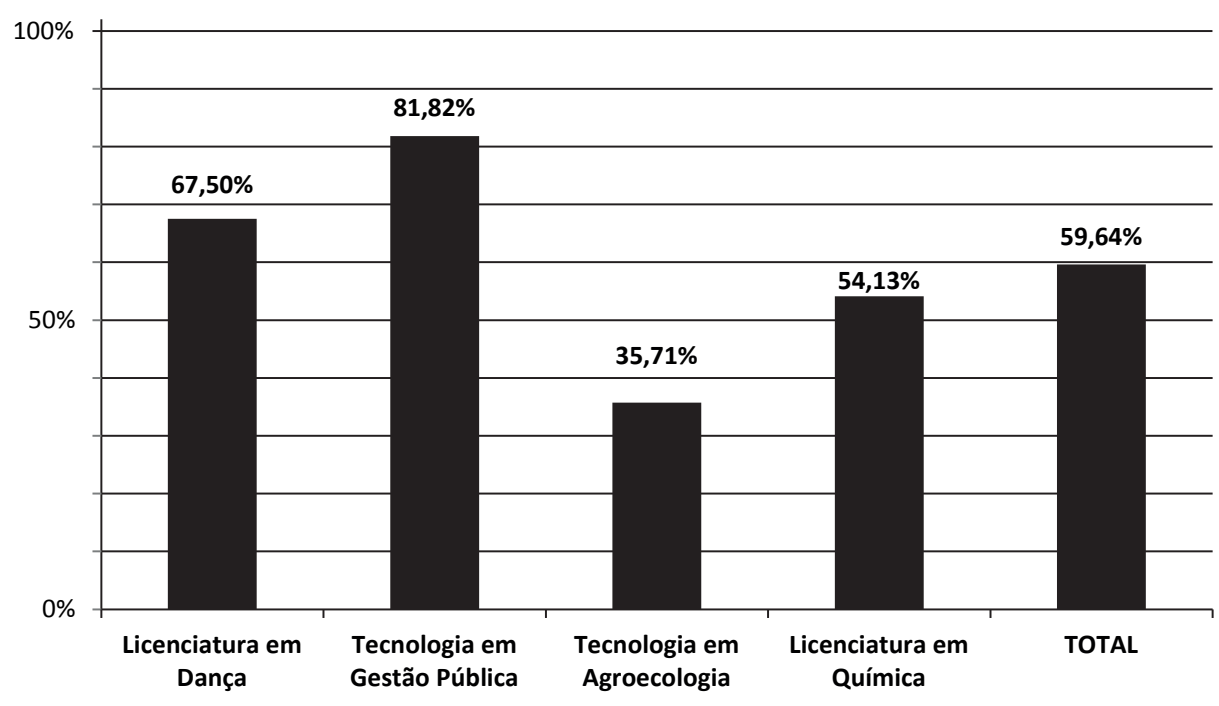


Gráfico 2 - Percentual de evasão nos cursos técnicos.

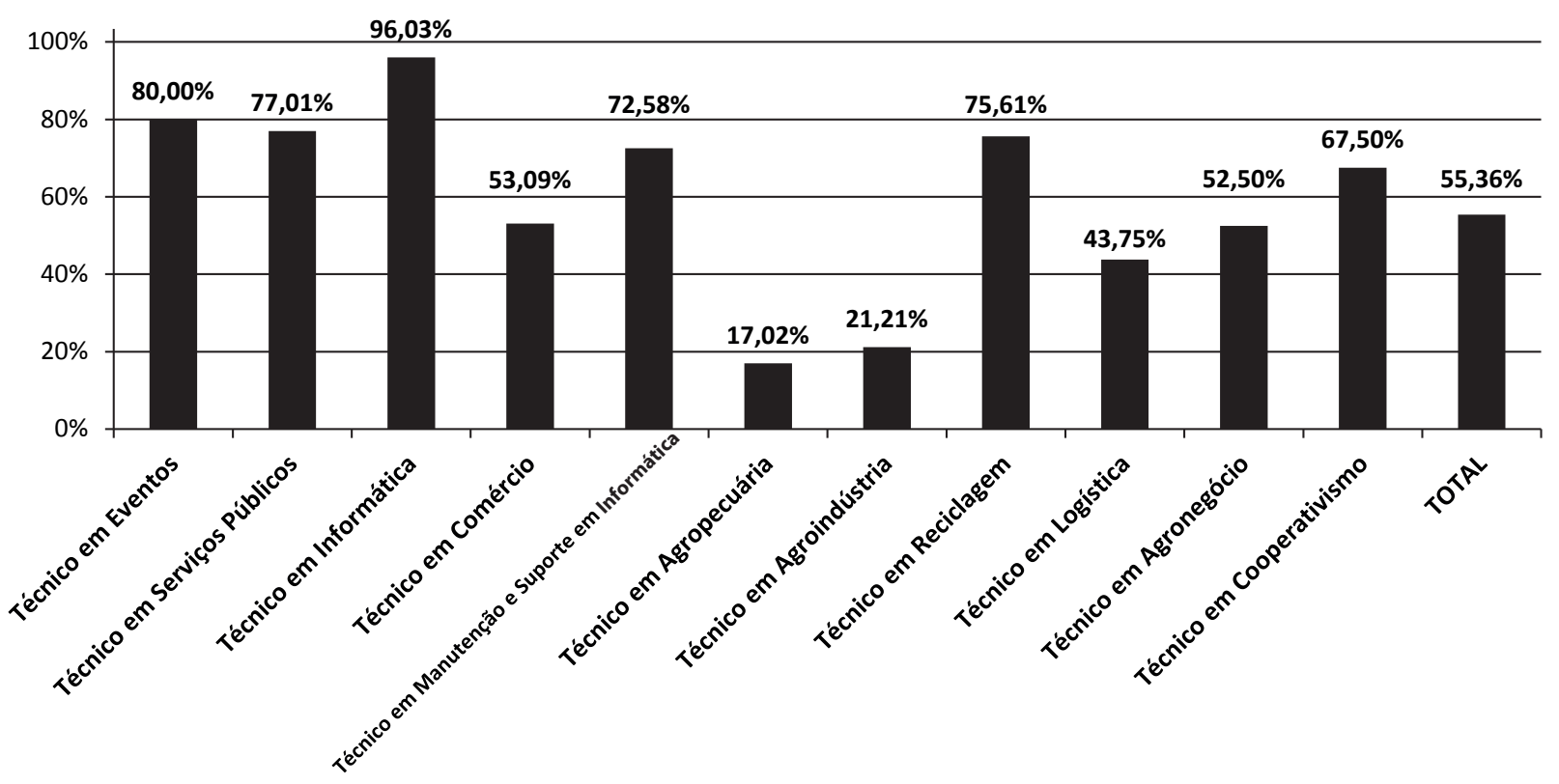

Quadro 1 - Curso técnico (cursos concluídos).

\begin{tabular}{|c|c|c|c|c|c|}
\hline Curso (recorte) & $\begin{array}{l}\text { Período da Oferta } \\
\text { (recorte) }\end{array}$ & $\begin{array}{l}\text { Recebimento } \\
\text { dos Dados }\end{array}$ & $\begin{array}{c}\text { Alunos } \\
\text { Matriculados }\end{array}$ & $\begin{array}{c}\text { Alunos } \\
\text { Evadidos }\end{array}$ & Evasão \% \\
\hline Técnico em Eventos & $1 s / 11$ a $2 s / 12$ & maio/14 & 80 & 64 & $80,00 \%$ \\
\hline Técnico em Serviços Públicos & $1 s / 11$ a $2 s / 12$ & maio/14 & 87 & 67 & $77,01 \%$ \\
\hline Técnico em Informática & $1 \mathrm{~s} / 11$ a $2 \mathrm{~s} / 12$ & maio/14 & 126 & 121 & $96,03 \%$ \\
\hline Técnico em Comércio & 08/10 a 07/12 & julho/12 & 81 & 43 & $53,08 \%$ \\
\hline $\begin{array}{l}\text { Técnico em Manutenção e } \\
\text { Suporte em Informática }\end{array}$ & $02 / 11$ a $12 / 12$ & março/14 & 62 & 45 & $72,58 \%$ \\
\hline Técnico em Agropecuária & $07 / 09$ a 12/11 & julho/12 & 235 & 40 & $17,02 \%$ \\
\hline Técnico em Agroindústria & $01 / 09$ a $12 / 11$ & julho/12 & 33 & 7 & $21,21 \%$ \\
\hline Técnico em Reciclagem & 08/10 a 07/12 & julho/12 & 41 & 31 & $75,60 \%$ \\
\hline Técnico em Logística & $08 / 10$ a $07 / 12$ & julho/12 & 80 & 35 & $43,75 \%$ \\
\hline Técnico em Agronegócio & 02/11 a 07/12 & julho/12 & 40 & 21 & $52,50 \%$ \\
\hline Técnico em Cooperativismo & 02/11 a 07/12 & julho/12 & 40 & 27 & $67,50 \%$ \\
\hline TOTAL & $01 / 09$ a $12 / 12$ & $\begin{array}{l}\text { *conf. datas } \\
\text { acima }\end{array}$ & 905 & 501 & $55,35 \%$ \\
\hline
\end{tabular}

Fonte: Campus Brasília; Campus Taguatinga Centro; Campus Taguatinga; Campus Planaltina; Campus Samambaia; Campus Gama e Sistec/Mec. 
Quadro 2 - Curso superior.

\begin{tabular}{|c|c|c|c|c|c|}
\hline Curso (recorte) & $\begin{array}{c}\text { Período da Oferta } \\
\text { (recorte) }\end{array}$ & $\begin{array}{l}\text { Recebimento } \\
\text { dos Dados }\end{array}$ & $\begin{array}{c}\text { Alunos } \\
\text { Matriculados }\end{array}$ & $\begin{array}{c}\text { Alunos } \\
\text { Evadidos }\end{array}$ & Evasão \% \\
\hline Licenciatura em Dança & $\begin{array}{c}2 \mathrm{~s} / 10 \text { a } 2 \mathrm{~s} / 14 \\
\text { (em andamento) }\end{array}$ & maio/14 & 80 & 54 & $67,5 \%$ \\
\hline Tecnologia em Gestão Pública & $\begin{array}{c}\mathrm{s} / 12 \text { a } 1 \mathrm{~s} / 15 \\
\text { (em andamento) }\end{array}$ & maio/14 & 44 & 36 & $81,81 \%$ \\
\hline Tecnologia em Agroecologia & fev./11 a dez./13 & março/14 & 42 & 15 & $35,71 \%$ \\
\hline Licenciatura em Química & $\begin{array}{l}\text { mar./12 a dez./15 } \\
\text { (em andamento) }\end{array}$ & março/14 & 109 & 59 & $54,12 \%$ \\
\hline TOTAL & ago./10 a dez./15 & março/14 & 275 & 164 & $59,63 \%$ \\
\hline
\end{tabular}

Fonte: Campus Brasília; Campus Planaltina; Campus Gama e Sistec/Mec.

Cabe observar que nem sempre é possível obter a exatidão dos percentuais, considerando que o ponto crucial incide no índice de perda, ótica que inclui situações além da situação que se convencionou como evasão, ou seja, não podemos fechar os olhos para os casos de reprovações, trancamentos, cancelamentos, outros. Tudo é perda. Nem sempre as estatísticas consideram essas ocorrências. Decorre desse parecer a decisão de ouvir o maior número de alunos e dar especial atenção ao que subjaz em sua fala.

O problema da evasão escolar tornou-se, na atualidade, o grande desafio e desafeto das instituições, notadamente das públicas, mas sem isentar as particulares, em todos os níveis e modalidades de ensino.

A alta evasão escolar nos cursos superiores é uma realidade presente em todos os Estados do país, em Instituições de ensino públicas e privadas (SOUZA, 2013, p. 5).

Por outro lado, não há muitas publicações a respeito, sendo notória, em grande parte das existentes, a especificidade de questões focalizadas, diferentemente em cada pesquisa, embora sob o mesmo tema - o da evasão. Esse tratamento diferenciado encontrado nas pesquisas favorece, de certa forma, dispersão nos resultados, embora todos de grande valia, considerando cada trabalho visar a um ponto diferente. Ou seja, as pesquisas existentes a respeito da evasão apresentam, não raro, ênfases diferentes, objetivos diferentes: relação da forma de ingresso com a evasão; origem dos alunos versus evasão escolar; eficiência das políticas afirmativas relacionada com permanência; evasão pontual em determinado curso ou área; entre outros enfoques.

Souza (2013), a exemplo, em busca no Banco de Teses da CAPES, utilizou, "como critério de procura pesquisas sobre a evasão no ensino superior e ação afirmativa. O resultado desta busca foi a localização de 134 teses/dissertações sobre o assunto - Evasão ensino superior, e 62 teses/dissertações sobre o assunto - Ação afirmativa educação superior, no entanto grande parte dos trabalhos sobre este assunto tem ênfase nas políticas de cotas raciais."

Silva (2011), por outro lado, focaliza em sua pesquisa sobre Evasão Escolar no IFBA, Campus Eunápolis, o perfil dos alunos evadidos ou que pensam em evadir e as prováveis causas dessa evasão.

Durante o transcorrer desta pesquisa, as questões centrais, com as quais não cansávamos de nos indagar eram: quem são os alunos evadidos e a evadir? Por que evadem ou pensam em evadir da instituição? (SILVA, 2011, p.2).

Klein e Freitas (2011), por sua vez, propõem investigar os motivos do abandono escolar na Educação de Jovens e Adultos do Estado do Paraná.

A causa trabalho teve sua maior concentração no sexo
masculino, por sua vez, as opções gravidez e/ou filhos
pequenos e afazeres domésticos foram apontadas
exclusivamente por mulheres, que, por vezes, além de
exercer uma atividade remunerada precisam cuidar da
casa e filhos (KLEIN e FREITAS, 2011, p.9).

Ajala (2011), também do Estado do Paraná, aborda a mesma modalidade - EJA -, enfocando, porém, os motivos de abandono da escola regular e motivos do retorno na modalidade EJA e expectativas pós EJA em Santa Helena-PR.

Quanto aos motivos que levaram estes alunos a abandonar a escola de ensino regular, na maioria dos casos isto ocorreu devido à falta de renda familiar e, consequentemente, à necessidade de trabalhar fora. (...) Mesmo após tantos 
anos afastados da escola, estes indivíduos perceberam a necessidade dos estudos, da aquisição de conhecimentos em suas vidas visando melhoras na qualidade de vida (AJALA, 2011, pp.32-34).

Trata-se de trabalhos preciosos, com certeza pouco ou nunca multiplicados com o mesmo foco, fato provável que justifica considerar-se como escasso o número de fontes.

Os números de casos de evasão ocorridos no IFB não diferem de números apresentados em outras instituições. Podem ser considerados alarmantes como nos demais casos que preocupam todos os estados do país, bem como classificados na ordem geral dos problemas sociais e políticos brasileiros.

Entre os dez estados com maior índice de abandono, sete são dessa região (Nordeste) - dois são do Norte (Pará e Amapá) e um do Sudeste (Rio). Na rede estadual de Alagoas (Região Nordeste), a taxa de abandono chegou a $21 \%$ em 2010, a maior do Brasil. (Folha de São Paulo, 2011).
Comparativamente aos países do Mercosul, a evasão escolar ocorrida no Brasil também é destaque como ainda sendo "um dos grandes problemas da educação brasileira. De acordo com a Síntese de Indicadores Sociais, divulgada em 2010 pelo IBGE (Instituto Brasileiro de Geografia e Estatística), o Brasil tem a maior taxa de abandono escolar no Ensino Médio entre os países do Mercosul. Segundo a pesquisa, 1 em cada 10 alunos entre 15 e 17 anos deixa de estudar nessa fase. No Ensino Fundamental os índices de evasão são menores, 3,2\%, mas ainda estamos atrás de outros países da América do Sul (Indice, 2014).

A taxa de abandono escolar é um dos principais fatores para o fraco desempenho do Brasil em indicadores educacionais quando comparado a outras nações. De acordo com o IBGE (2014), apesar de o País ter registrado uma queda de $11,5 \%$ na taxa de abandono do ensino de 2001 para 2011 entre jovens com 18 e 24 anos, essa média ainda é três vezes maior do que o percentual verificado em 29 países europeus. 
Gráfico 3 - Taxa de abandono escolar precoce da população de 18 a 24 anos de idade, por sexo, segundo países europeus e Brasil - 2011 (IBGE (2012).

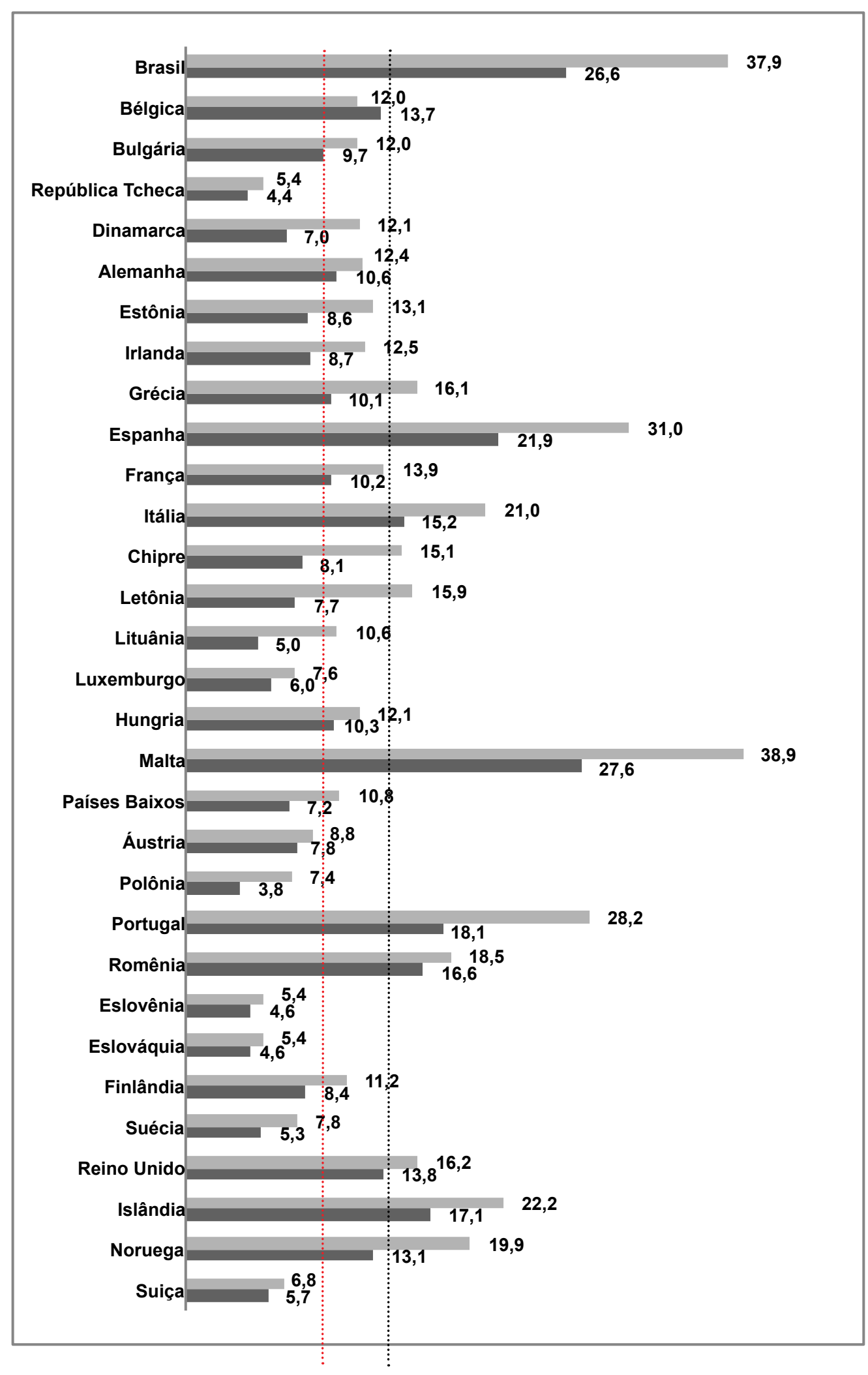




\section{Objetivos}

O objetivo da pesquisa, na condição de instrumento de avaliação permanente, é fornecer à Instituição subsídios, como instrumentos de meta-avaliação (GREGO, 1997), a fim de favorecer intervenções pontuais que se façam necessárias, nos campos pedagógico, administrativo, de ingresso, curricular, e em outros de cunho organizacional e social, de forma que contribua para minimizar a vulnerabilidade da permanência do aluno na escola, bem como as barreiras de acesso, e para consolidar a terminalidade.

Segundo José Dias Sobrinho, "para além da contabilidade e da mensuração dos produtos e de todos os índices quantificáveis e capturáveis em tabelas e estatísticas, avaliar uma instituição é compreender as suas finalidades, os projetos, a missão, o clima, as pessoas, as relações sociais, a dinâmica dos trabalhos, a disposição geral, os grupos dominantes e as minorias, os anseios, os conflitos, os valores, as crenças, os princípios, a cultura" (SOBRINHO, 1997, p.73).

Uma característica marcante do trabalho de escuta, que nos incentivou sobremaneira, e uma das principais, é a de mostrar-se como janela segura de avaliação permanente da instituição. Trata-se de um instrumento de avaliação que se faz por contato direto com os objetos passíveis de análise, trazendo uma visão mais fidedigna a respeito de vários aspectos da instituição, por não se limitar, apenas, a constatações numéricas. Independentemente de ter como foco principal o estudo das causas de evasão, a observação direta permite-se estar a serviço de outros interesses da Instituição, principalmente no que concerne à questão pedagógica, à oferta de cursos e às questões estruturais. Lacunas, expressas ou não, em algumas falas advindas dos próprios entrevistados não podem passar em branco nos processos de avaliação institucional. Relacionamento professor-aluno, avaliação, didática, clareza dos enunciados e sobre o que se espera do aluno, informação prévia sobre o que será avaliado, despreparo de professores, relação entre teoria e prática e estrutura do curso são alguns temas suscitados nos depoimentos dos evadidos, sugestivos para capacitações docentes e técnico-administrativas e como pautas de discussão, oriundas do próprio contexto do IFB.

- Informante 1 - As aulas não eram dinâmicas; havia muita teoria e isso cansava! As aulas um tanto teóricas.

- Informante 2 - Problema com nota. Nunca consegui ver minhas provas. Só a nota, embora tenha pedido ao professor. Enviei e-mail para o professor mas nunca obtive resposta. Tive uma decepção muito grande em função de nota, pois se tratava de uma disciplina que lida com a parte mais simples. Acabei desistindo. Minha decepção também é em função de não me conformar pois trabalho com a área faz 25 anos.

- Informante 3 - Na minha percepção os professores não estavam comprometidos com a aprendizagem da gente, sem falar que não tinham habilidade nenhuma interpessoal.

- Informante 4 - Acho importante dizer por que saí. Já trabalho na área. Sou concursado. A estrutura do curso, sua organização e qualidade não são boas. Também critico o despreparo de alguns professores, o tratamento ruim aos alunos. E eu soube que de 40 alunos apenas 6 se formaram.

- Informante 5 - Na sala, à noite, achava que alguns professores davam mais atenção aos alunos que já sabiam. Como eu não sabia e não era bem assistida, eu desisti.

- Informante 6 - Saí tão decepcionado que nem deveria dar qualquer satisfação sobre essa solicitação. Mas se tomasse essa atitude estaria sendo deselegante com quem não teve nada a ver com minha desistência. Desisti porque me senti humilhado por um professor. Durante a apresentação de um trabalho em sala de aula, fez tanto deboche da nossa apresentação que não tive mais condição psicológica nem para voltar à secretaria e dizer que estava desistindo do curso. O professor não explicou como queria que apresentássemos o trabalho e ainda se achou no direito de cobrar, de tal forma que me senti humilhado perante os meus pares.

Por outro lado, a leitura realizada por meio de contato direto com os alunos evadidos, quando associada a leituras numéricas, também permite uma visão clara dos efeitos de medidas tomadas outrora pela instituição, além de mostrar, com grande margem de segurança, o seu andamento interno e os anseios externos, sinalizando tomadas de decisões mais eficazes. Nessa perspectiva, muito nos auxilia a transposição dos conceitos de metaavaliação para o contexto da nossa pesquisa. "A avaliação da avaliação (meta-avaliação), uma área de estudo que vem sendo extensivamente desenvolvida e aplicada, constitui importante referencial de análise para a melhoria da qualidade de projetos e programas de avaliação educacional" (GREGO, 1997, p. 94). 
É evidente o aumento de ocorrências relacionadas a problemas de ordem didático-pedagógica. Percebe-se que à medida que a Instituição cresce, essa ordem de problema também aumenta, tendo em vista a diversidade de profissionais e de alunos que passa a compor o quadro de servidores e discentes. Trata-se de um processo natural de inclusão. É sintomático. Daí a importância de aumentar e disseminar o número de capacitações com profissionais habilitados e de encontros permanentes entre os pares.

\section{Metodologia}

A escolha do período, da modalidade, dos cursos e dos campi a serem observados foi o primeiro passo.

Definidas essas questões e de posse dos dados a respeito da evasão, entramos em contato com os campi envolvidos, a fim de que nos enviassem o endereço eletrônico e/ ou telefone dos alunos cujos nomes constavam na lista fornecida pelo Sistec. Conforme os campi iam nos dando retorno, íamos enviando um e-mail, com texto padronizado, apenas com a diferença dos dados de curso e período, para aqueles alunos evadidos cujos endereços eletrônicos constavam na lista devolvida pelos campi.

O Instituto Federal de Brasília, com o intuito de aprimorar todas as ofertas de cursos, tem buscado as razões que levam alguns alunos à desistência. Solicitamos a gentileza de nos informar o que o (a) motivou a desistir do curso $X$ (período de X a X), oferecido pelo Campus X. Agradecemos sua atenção. Atenciosamente.

Considerando que nem todos os alunos responderiam ao e-mail, houvemos por bem acrescentar um parágrafo no corpo da mensagem, nos períodos em que havia inscrições abertas, com o intuito de garantir o informe, antecipando-o.

Na oportunidade, informamos que há inscrições abertas (até o dia X) para alguns cursos e campi, divulgadas no site do IFB - www.ifb.edu.br.

Sequer um aluno evadido a quem tivemos acesso ficou sem resposta, após justificar sua desistência. O trabalho de escuta cumpre também o papel de orientador e incentivador de retomadas de estudo, por parte dos alunos. Tem o poder de exercer vários papéis. A informação, que estaria reduzida à propaganda, quando dentro de um contexto especial, ganha novos contornos e faz as vezes de orientação personalizada. É interessante, pois essa intenção chega ao aluno.
- Informante 1 - Agradeço o envio, creio que o feedback pode contribuir muito para o avanço do processo. Parabenizo pela ação em busca dos motivos da evasão. Se conseguirmos o acompanhamento prévio, concomitante e posterior, com certeza o número de evadidos irá cair. Obrigada, não me senti só um número.

- Informante 2 - Agradeço o interesse e a preocupação. Tenho certeza que essa iniciativa irá contribuir para a esfera educacional e a comunidade em geral. Desde já agradeço de coração a sua atenção e parabéns pelo excelente trabalho!!! (...) o diferencial que o nosso país precisa! Um grande abraço.

- Informante 3 - Acho muito interessante essa preocupação do IFB.

Esclarecemos que interferimos na ortografia de algumas palavras, assim como em alguns casos de concordância e na pontuação de alguns trechos dos e-mails enviados pelos alunos, em favor da clareza, bem como omitimos algumas informações, em cumprimento a preceitos éticos. No mais, preservamos a fluidez da mensagem.

Àqueles alunos que não responderam ao nosso apelo por e-mail telefonamos.

Todos os alunos com quem conversamos foram informados sobre inscrições que estivessem abertas ou com datas previstas. Coincidentemente muitos contatos foram feitos nos períodos que antecederam esses prazos. Pela fala da maioria e receptividade demonstrada, principalmente daqueles que tiveram impedimentos temporários para continuarem o curso, foi possível visualizar tentativa de retorno. Também, sem exceção, esses alunos foram orientados a acompanhar o site do IFB. Muitos já o fazem; alguns sequer conheciam sua existência, ou simplesmente não sabiam o endereço.

Selecionamos algumas trocas de e-mails, com a finalidade de mostrar essa fase do procedimento, ilustrar o contato feito e elucidar o universo de possibilidades de análise para medidas futuras implicadas nos depoimentos. Lembramos que todas as conversas foram iniciadas com o envio do texto padronizado para esse fim, por meio do comunicante do IFB.

Houve até um prolongamento de conversa, em alguns casos, como se mostra abaixo. Trata-se de diálogos em que transparecem frutos desdobrados como setas orientadoras para tomadas de decisão - sugestões, críticas, outros além da resposta da evasão e aproximação do aluno ao IFB. 


\section{Conversa 1}

- Informante-Bom dia. O que me levou a desistir do curso de Reciclagem foi simplesmente por opção. Vi que não era meu objetivo profissional, já que estou na área de elétrica e quero fazer Engenharia Elétrica. Atenciosamente.

- Comunicante do IFB - Bom dia. Obrigada pelo retorno. Desejamos sucesso em sua escolha. Lembramos que por meio do site do IFB (www.ifb.edu.br) você poderá acompanhar as informações a respeito da Instituição. $A$ propósito, não sei se é do seu conhecimento que o Campus Samambaia já tem sua sede própria. O endereço é: Subcentro Leste, Complexo Boca da Mata, Lote 1 - Samambaia-DF - Fone: + 55 (61) 2103-2300. Att.

- Informante - Sei sim... Obrigado! Vocês vão implantar os cursos superiores aí? Tem possibilidade que ter engenharias aí?!

- Comunicante do IFB - Há alguns cursos em fase de aprovação nos diversos campi do IFB. Especificamente Engenharia, no momento não há informação divulgada. Como disse, é interessante acompanhar o site, pois o Instituto está em fase de expansão. Att.

- Informante - Obrigado pela atenção. Atenciosamente.

- Comunicante do IFB - De nada. Att.

- Informante - Olha que peço mais... rsrs...

- Comunicante do IFB - O que estiver ao meu alcance farei para ajudar a quem precisar. Tenho certeza de que o IFB ficará feliz em ver o seu retorno. Um abraço e Feliz Natal!

- Informante - Eu vou querer só se tiver engenharia... Mas aí é outra etapa... Mas quem sabe daqui uns anos terá.... O importante é se profissionalizar e sei que o IFB é uma instituição que vai capacitar várias pessoas... Obrigado e Feliz Natal e um próspero Ano Novo... Grande abraço para você também...

\section{Conversa 2}

- Informante - Oi, bom dia! Serei sincero em dizer o porquê de ter desistido! Quando comecei o curso, estava empolgadíssimo, e me arrependo até hoje por ter abandonado. Eu estava fazendo o curso de Serviços Públicos aí no IFB todos os dias, durante a noite, e nos fins de semana fazia pós-graduação em Gestão Pública o dia todo. Como trabalho das 8 às 18h, estava saindo de casa às 6 h40 da manhã e chegando sempre depois das 23h, e com isso não estava tendo mais nenhum contado com meu filho, porque quando eu saía de casa para trabalhar ele estava dormindo, e quando chegava à noite também. Na época tinha 5 aninhos e isso estava me deixando com muita saudade. Graças a DEUS consegui terminar a pós-graduação, porém tenho toda a certeza de que o curso de Serviços Públicos seria mil vezes melhor para o meu aprendizado e para minha carreira. Peço desculpas por ter até talvez tirado a vaga de uma outra pessoa, mas agora meu filho já está maior. Espero em breve voltar a estudar aí no IFB e crescer ainda mais profissionalmente. Att.

- Comunicante do IFB - Bom dia. Somos gratos pelo seu retorno. A educação e atenção aos filhos sempre é uma causa nobre. Tenha certeza disso. Oportunidades reaparecem, mas o desenvolvimento dos filhos não volta atrás. Conforme já informamos, há inscrições abertas para alguns cursos, nos diversos campi do IFB. Não exatamente do Curso Técnico em Serviços Públicos, mas, dentre os cursos, há os chamados FIC - de Línguas, que, com certeza, são complementos de estudos. Estão sendo oferecidos em Samambaia e Riacho Fundo. Reiteramos a sugestão de manter contato por meio do site do IFB - www.ifb.edu.br - em que as oportunidades são sempre divulgadas. Att.

- Informante - Eu que me sinto lisonjeado por ter recebido o seu e-mail. Tenha certeza de que este simples e-mail me fez sentir o quanto ainda tem pessoas boas neste nosso país. Muito obrigado! Att.

- Comunicante do IFB - Agradecemos novamente o seu retorno. Na Educação, isso nos faz ver que "vale a pena".

- Informante - Desejo-Ihe em 2013 muitas realizações e sucesso. Estamos envolvidos com um mesmo propósito: "melhorar a educação em nosso país". (...)Grande abraço.

- Comunicante do IFB - Feliz 2013 para você também. Sucesso no seu trabalho. Um abraço. 


\section{Conversa 3}

- Informante - Olá, tudo bem? Eu desisti do curso porque, e infelizmente, no começo do curso não era possivel trancar a minha vaga. Tive problemas familiares muito sérios que não podiam esperar mais 6 meses de curso pra serem resolvidos e até busquei ajuda com um dos professores, mas como nada podia ser feito, apenas tive que desistir. Hoje tenho um interesse enorme pra voltar pro curso, mas fico um pouco desanimado em ter que pensar em todo o processo novamente. Pra mim, acredito apenas que falte uma sensibilidade maior em escutar os alunos e tentar ajeitar ao máximo as situações. Se caso for possivel recuperar minha vaga, não esqueça de me avisar, ok?!

- Comunicante do IFB - Bom dia. Obrigada pelo retorno. Creio que ficará feliz em saber que as inscrições para a Licenciatura em Dança estão abertas. Vão até o dia 28 de janeiro. As informações estão na primeira página do site. Sugiro que mantenha contato por meio do site do IFB - www.ifb.edu.br-em que novas oportunidades sempre são divulgadas. Att.

As conversas acima transcritas revelam o leque de possibilidades que traz o recurso escolhido para termos acesso a esse aluno evadido, o qual, assustadoramente, na maior parte das vezes permanece no anonimato, compondo apenas o índice de perda na Educação. Além disso, trata-se de um filtro natural de sugestões e apontamentos de problemas a serem corrigidos. Nesse espaço, a gentileza, a camaradagem e a franqueza coabitam nos diálogos, sem se repelirem ou se contraporem, tampouco nublarem, com a permissividade da bajulação ou da agressividade, a avaliação que se faz naturalmente da instituição a partir do diálogo estabelecido entre Instituição e aluno. Pelo contrário, aproximam, gerando confiança e credibilidade - pontos fundamentais para o retorno do aluno evadido.

No rol de depoimentos, havemos de lembrar a conhecida frase "Nem tudo são flores". Trata-se de críticas mais contundentes que devem ser observadas com apreço como qualquer elogio ou sugestão. Aliás, talvez com peso maior, pois podem originar temas de capacitações dos profissionais e indicadores para reestruturações. Esse é o papel principal de qualquer avaliação.

\section{Conversa 4}

- Informante - Os motivos pelos quais desisti do curso estão relacionados à falta de estrutura do órgão e ao despreparo de alguns educadores, que por diversas vezes agiram de forma desrespeitosa, irônica, e alguns sempre demonstraram um certo desânimo para com a turma de ensino que eu cursava. Motivos pelos quais acabaram todos os encantos e expectativas que depositei tanto no curso quanto no órgão. A partir desses acontecimentos não encontrei forma de motivação positiva, e então optei pela desistência. Espero que tais acontecimentos tenham sido insolados, ou motivados apenas por se tratar de um curso experimental. E que todas as irregularidades, seja na conduta de alguns educadores, alunos ou administrativos tenham sido sanadas, e que o aprendizado seja um objetivo comum, assim como o respeito ao próximo, visando sempre melhorias para ambas as partes...Atenciosamente.

- Comunicante do IFB - Boa noite. Lamentamos muito situações como a relatada em seu e-mail, e ainda mais pelo fato de culminar em sua desistência. Este trabalho de pesquisa visa, exatamente, à melhoria de oferta de cursos, em todos os seus aspectos. Esperamos que o fato mencionado não seja causa de impedimento de seu retorno, considerando, inclusive, a expansão do Instituto, que oportuniza a todos a inserção em outros cursos, em outros campi, em outros contextos, mesmo sendo no mesmo campus. Desejamos, e esta pesquisa concorre para isso, que, em futuro breve, esses desajustes mencionados realmente representem e se tornem apenas um fato isolado, fato pontual, que não influencie a continuidade de sua trajetória estudantil. A propósito, as inscrições para alguns cursos, nos diversos campi do IFB, vão até o dia 29 de janeiro ( e 28 de janeiro para a Licenciatura em Dança), e todas as informações a respeito estão divulgadas no banner principal do site. Att. 
Conforme a instituição vai se construindo, a procura também vai de delineando. Consequentemente e de forma natural e esperada o grau de exigência e a visão crítica se fazem presentes. Essa presença é reveladora. Preocupante seria se fosse velada. Embora pontual, o depoimento torna-se ilustração de crítica importante a ser considerada como objeto de avaliação e atenção. A partir de então, se visto nessa perspectiva, torna-se positivo.

Todos os dados foram digitados e/ou arquivados, logo após o contato, fosse por e-mail ou telefone, a fim de que não perdêssemos da memória impressões, que complementam, em muitos pontos, as falas textuais e esclarecem entrelinhas.

No tocante à análise após a coleta de dados, Ludke e André (1986, p.48) afirmam que é preciso que a análise não se restrinja ao que está explícito no material, mas procure ir mais a fundo, desvelando mensagens implícitas, dimensões contraditórias e temas sistematicamente "silenciados".

Reside aí a importância de se considerar a fala em sua totalidade, mesmo que, em alguns momentos, a pessoa observada exponha argumentos outros, aparentemente alheios ao objeto da pesquisa. De acordo com Rojas, Fonseca e Souza (2010, p.2),

Na pesquisa qualitativa em que a intencionalidade do pesquisador é conhecer o seu sujeito e desvelar suas ações tendo como ponto de partida os depoimentos, as respostas, as observações, o diálogo, deve-se salientar o enunciado como revelador de quem fala, que se mostra pela linguagem.

Após a fase de todo o levantamento das causas da evasão, foi dado início ao agrupamento dos dados. A título de melhor compreensão da leitura deste trabalho, foi dada especial atenção às análises dos depoimentos dos entrevistados, considerando o que trazem de conteúdo para medidas de prevenção e autoavaliação institucional. Deliberou-se a organização dos dados por classes de problemas, hierarquizados sob a consideração de que estes apresentam uma causa central que traz em sua composição, na maioria das vezes, outras causas, em alguns casos subjacentes, as quais, embora nem sempre se revelem explicitamente, muitas vezes têm peso maior no conjunto de motivos que ocasionou a evasão. Um problema gerador (causa central), como "trabalho", por exemplo, apresenta de forma subjacente muitos outros impedimentos, aparentemente menores, mas que são responsáveis pela evasão. Às vezes funcionam apenas como explicação da causa central. A alegação "trabalho" nem sempre é fidedigna. Com frequência resume um rol de problemas, não sempre visíveis, que se interpõem entre o trabalho e o estudo. Porém, esses problemas (que normalmente não aparecem nos quadros estatísticos) muitas vezes são os canais de acesso da escola ao aluno, para possíveis intervenções. O número de alegações que dizem respeito ao trabalho é muito grande. Mas o que está por trás "do trabalho", não raro, é a distância, a alimentação, o transporte público, o cansaço decorrente...a falta de autossustentação, outros. A Instituição, quando pode intervir, atua, na maioria das situações apresentadas, nesse campo "periférico", e não no campo "gerador". Abrimos um parêntese aqui para explicar que lançamos mão dessas metáforas, na tentativa de usar termos que melhor classificassem as razões apresentadas pelos alunos. "Trabalho", então, estaria no campo "gerador". A instituição pode, nesse sentido, minimizar os efeitos das distâncias, disseminando cursos em várias regiões, oferecendo passe escolar, alimentação, outras medidas que já fazem parte de iniciativas em favor da permanência do aluno. Porém, não tem condições de gerar emprego ao aluno, seja na própria instituição, ou em suas proximidades, para resolver o problema da distância, do transporte, outros. Destaque-se que, mesmo em se tratando de causas subjacentes ao campo "gerador", há situações em que a instituição não tem como intervir. A exemplo, trazemos um caso de "trabalho", cuja causa subjacente é "disponibilidade de horário em função do cargo (de confiança, de chefia) que exerce" . Neste caso a instituição não tem como intervir. Registramos também a ocorrência de causas centrais em que não há indício de nenhuma causa subjacente, pelo menos extraída do depoimento, expressa ou veladamente. É o caso, por exemplo, de depoimentos como "problemas pessoais e/ou familiares", "acidente de trânsito".

Nessa perspectiva, procedemos à leitura desses dados, avaliando-os qualitativamente, na busca da compreensão de causas não expressas textualmente na fala do aluno, mas que aparecem veladas, seja no universo do evadido, seja no universo da Instituição.

Nem sempre é simples identificar qual a causa central e qual ou quais são subjacentes. Procuramos interpretar a fala dos entrevistados para classificar os motivos. Consequentemente, a precisão é vulnerável.

Outra informação importante é que uma mesma causa pode ser classificada como central em determinado contexto e, em outro, pode ser uma causa subjacente. Depende muito das explicações que o entrevistado nos fornece. A exemplo, houve um caso em que a pessoa mudou-se para outro Estado em função do trabalho. Neste caso, o "trabalho" é a causa central, e a "mudança de Estado" é a causa subjacente, ou seja, é a causa que é mencionada, quando é, em segundo plano. Já em outro depoimento, a 
"mudança de Estado" é a causa central, pois o aluno evadido precisava cuidar do pai, que lá morava. Provavelmente se o pai morasse em Brasília, esse aluno poderia conciliar a frequência ao curso com os cuidados ao pai. A mesma análise atribuímos em um caso semelhante, mas que se tratava da saúde do próprio aluno, o qual, em outro Estado, receberia os cuidados da família. Por inferência, consideramos que, se a família morasse em Brasília, esta poderia dar apoio ao aluno, e este não precisaria desistir do curso. Neste último caso, principalmente, não nos furtamos de considerar nossa análise passível de erro.

A soma das causas subjacentes pode ser menor do que a soma da causa central. Esse resultado se deve ao fato de que nem sempre o aluno evadido entra em detalhes sobre a causa que o motivou a abandonar. Simplesmente cita a causa como central. Por outro lado, pode ocorrer o contrário, ou seja, o número de causas subjacentes ser maior do que o número das ocorrências da causa central. Isso se deve ao tratamento que foi escolhido para a organização do cômputo dos dados. Neste caso, um mesmo aluno pode ter fornecido mais de uma alegação para a mesma causa central. Entendemos que todos os detalhes do conjunto de alegações que aparece na fala dos alunos são importantes para avaliação da Instituição. O importante é que cada alegação emanada de um único depoimento seja mencionada para conhecimento da Instituição.
Considerando o número de entrevistas realizadas, essa forma de leitura favorece a discriminação de cada parte da fala do aluno evadido. O resultado do mapeamento das justificativas apresentadas pelo entrevistado facilita à Instituição o acesso a indicadores seguros para tomada de decisões e acertos. Não raro, o aluno faz uma reflexão, enquanto se expõe durante o depoimento, mostrando todo o caminho percorrido que o levou à desistência. E as pedras desse caminho se dão em cadeia. Às vezes, é nesse momento que o próprio aluno evadido se dá conta disso, conforme algumas experiências vividas por nós na condição de pesquisador. Nessa hora, normalmente, mostra-se arrependido, grato pelo telefonema ou e-mail, e faz novos planos para retorno, ali mesmo durante a entrevista. Nem sempre é possível determinar uma única causa para a sua desistência, tampouco a mais importante. O que se observa com clareza é que por trás daquela causa que se supõe a principal há problemas outros que a motivaram. Daí a constatação de que, em grande parte das vezes, a uma causa central corresponde uma causa subjacente ou mais.

Dos 218 alunos entrevistados, dois não disseram o motivo. Apenas confirmaram que desistiram e que têm interesse em voltar. 
Gráfico 4 - Causas centrais (campo gerador).

\section{Total de 279 ocorrências (218 alunos ouvidos)}

Trabalho

2. Conciliação com outro curso / estágio;

Ingresso em outro curso; Opção por outro curso

3. Distância / Engarrafamento / Transporte / Acesso / Trânsito

4. Problemas no âmbito interno da instituição*

5. O curso não era o que esperava / não se interessou

pelo curso / não se identificou com o curso

6. Problemas pessoais / familiares

7. Problemas financeiros

8. Problemas saúde

9. Mudança de cidade / estado / país

10. Segurança

11. Não tinha com quem deixar o filho / fase de amamentação / gravidez

12. Acidente de trânsito

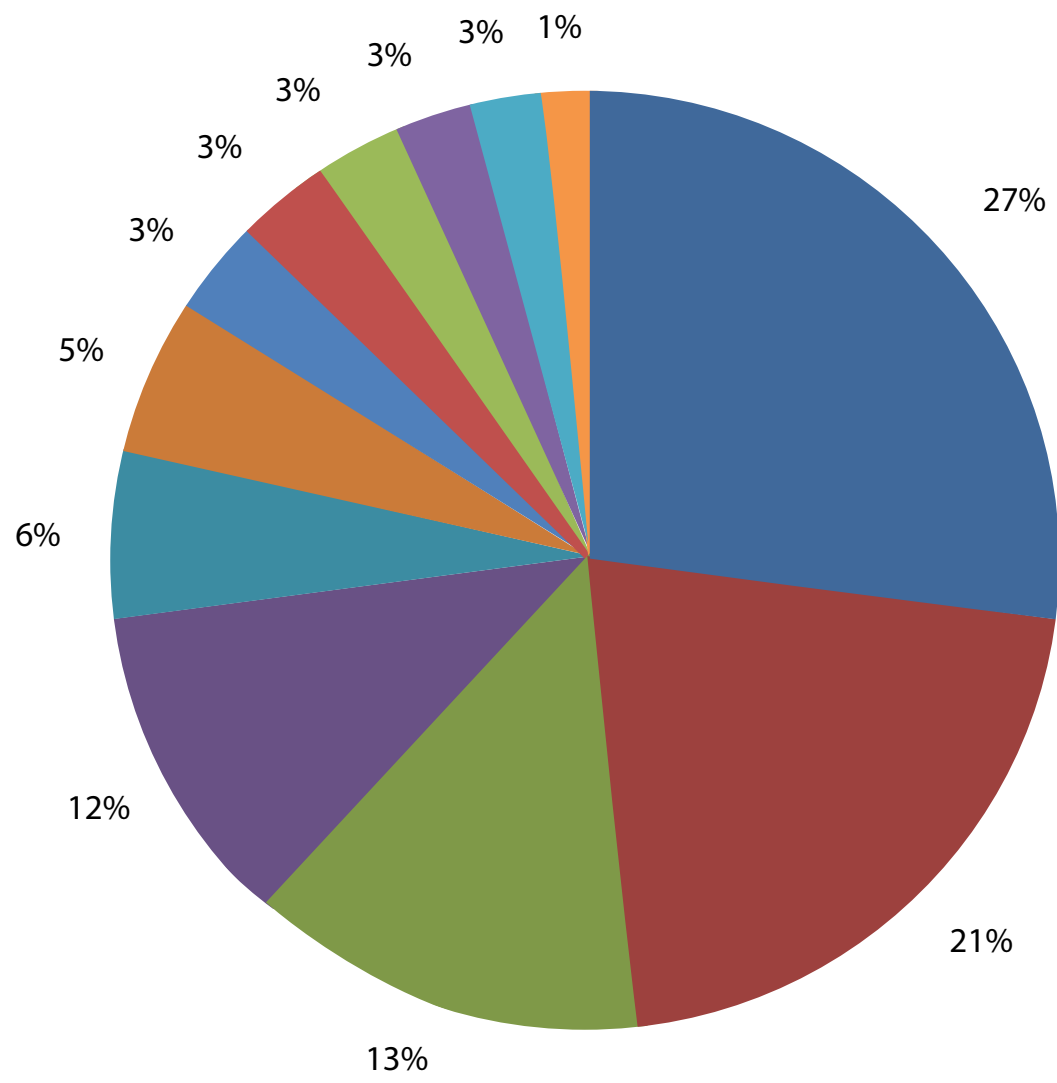

Deduz-se que em "Conciliação de horário" também há, implicitamente, motivos relacionados ao trânsito/ transporte. Estes não foram computados na causa central acima representada em verde claro, sob o número 3, pelo fato de se tratar de uma dedução.

Os gráficos 5 e 6 e o quadro 3 abaixo ilustram a correspondência entre causa central e causas subjacentes das ocorrências: "Trabalho (76 ocorrências)"; "Conciliação com outro curso/estágio, ingresso em outro curso, opção por outro curso (59 ocorrências, sendo que essa conciliação ocorreu na seguinte proporção: Superior = 38; Técnico/ Estágio/Cursos livres = 18; Pós-Graduação = 03)"; e "Problemas no âmbito interno da Instituição - de ordem estrutural /organizacional/curricular/pedagógica/ outros/ do curso e/ou da instituição" (32 ocorrências). 
Gráfico 5 - Correspondência entre a causa central "trabalho" e as causas subjacentes (há coincidência).

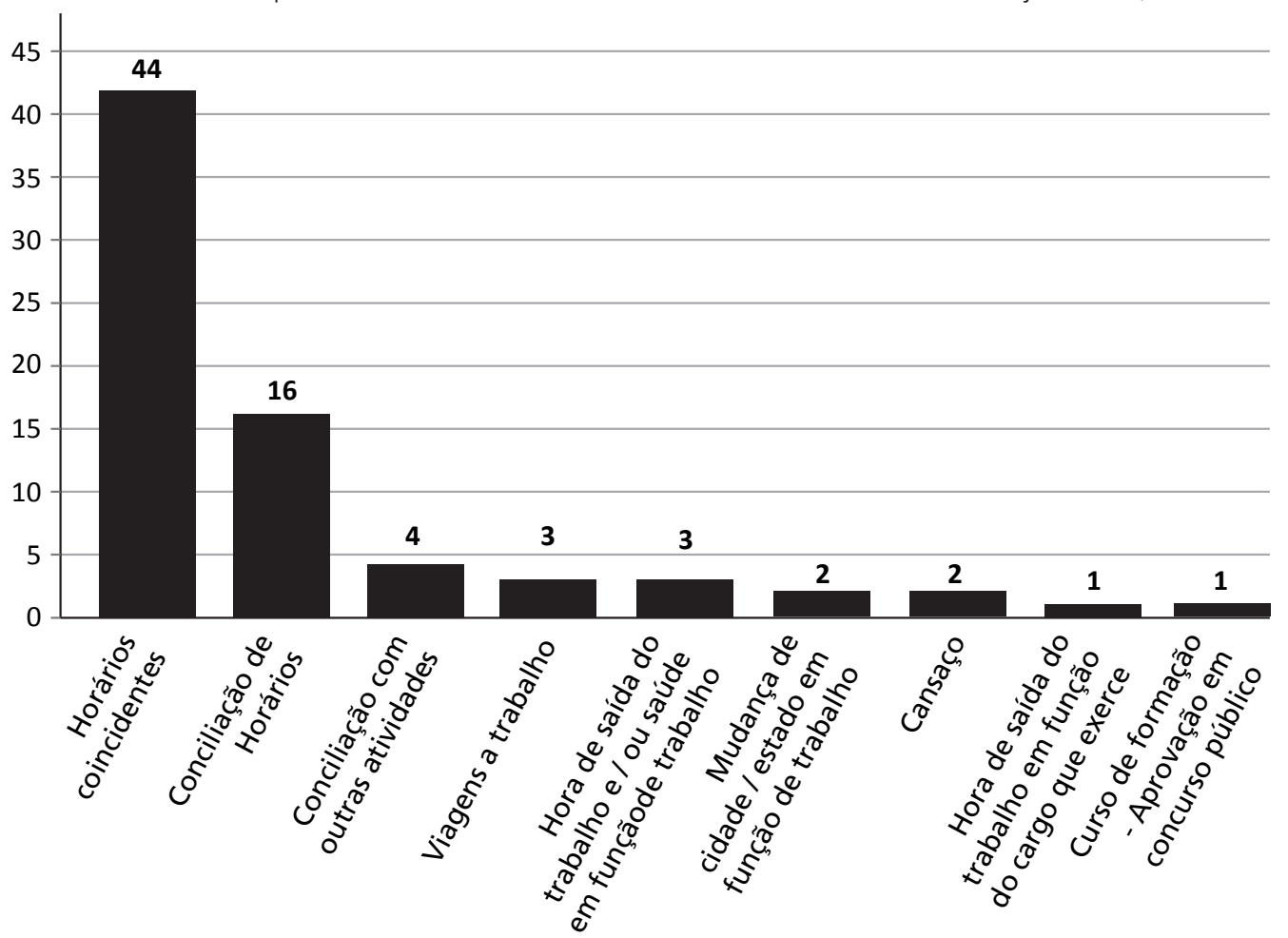

Gráfico 6 - Correspondência entre a causa central "Conciliação com outro curso/estágio; ingresso em outro curso; opção por outro curso" e as causas subjacentes (não há coincidência).

Número de Causas Subjacentes de Conciliação com outro curso / estágio; ingresso em outro curso; opção por outro curso

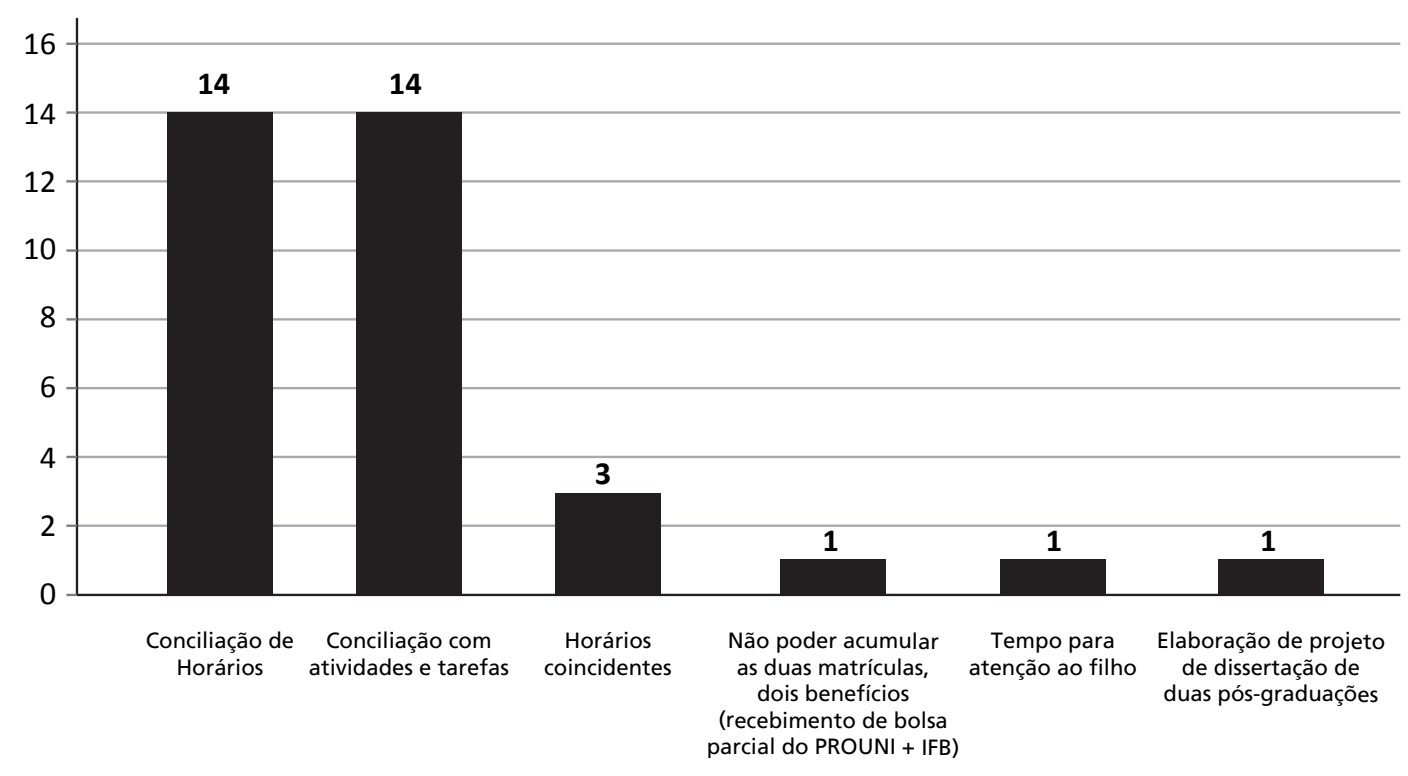


Quadro 3 - Correspondência entre a causa central "Problemas no âmbito interno da Instituição - Problemas de ordem estrutural /organizacional/curricular/pedagógica/outros do curso e/ou da instituição" (32 ocorrências) e as causas subjacentes (não há coincidência).

\begin{tabular}{|c|c|}
\hline OCORRÊNCIA & CASOS \\
\hline $\begin{array}{l}\text { Desmotivação/descrédito/tristeza/decepção/desestímulo* } \\
\text { * Grande parte em função das causas elencadas. }\end{array}$ & 07 \\
\hline Não acompanha as aulas/turma por falta de conhecimentos. & 06 \\
\hline Conduta de professores, alunos e servidores administrativos. & 01 \\
\hline Aulas não dinâmicas, aulas muito teóricas. & 01 \\
\hline Matérias vagas, sem relação com a prática. & 01 \\
\hline Não conseguia tirar dúvidas em algumas matérias. & 01 \\
\hline Não tinha acesso às provas. & 01 \\
\hline Professor dava atenção apenas a alunos que já sabiam. & 01 \\
\hline Conteúdo programático extenso. Crítica à distribuição da carga horária. & 01 \\
\hline Metodologia de determinada disciplina. & 01 \\
\hline $\begin{array}{l}\text { Processo de aproveitamento de disciplinas e trancamento (desencontro de informações/falta de } \\
\text { atendimento/ sumiço de pedido/implicação na duração do curso). }\end{array}$ & 06 \\
\hline Excesso de faltas. & 01 \\
\hline Falta de estrutura/organização do curso. & 03 \\
\hline Falta de estrutura/organização da instituição. & 02 \\
\hline Baixo nível do curso em função do sorteio. & 01 \\
\hline Não sentiu confiança no curso. & 01 \\
\hline Despreparo de alguns professores. & 03 \\
\hline Muita troca de professor; informações de poucas oportunidades no mercado de trabalho. & 01 \\
\hline Professores evasivos, sem didática e domínio de conteúdo. & 02 \\
\hline Não oferta de grade aberta (aluno já tem uma graduação). & 01 \\
\hline Necessidade de suporte tecnológico, orientação. & 01 \\
\hline Greve. & 04 \\
\hline Conduta do professor: humilhação do aluno perante a classe. & 01 \\
\hline Comprometimento de professores com a aprendizagem dos alunos e na relação interpessoal. & 01 \\
\hline Não tinha computador/internet (acesso à matéria que o professor deixava no e-mail). & 02 \\
\hline Dificuldade em duas matérias (aprendizagem e notas). & 01 \\
\hline Falta de professores. & 01 \\
\hline
\end{tabular}


Consideramos o todo dos depoimentos, e não apenas a "razão fria" de sua desistência. Não raro, o "entorno" é mais importante. Nasce daí a visão das causas que houvemos por bem adjetivar de "subjacentes" e/ou "periféricas". Nessa forma de observar a vida e fazer pesquisa, encontramos amparo em estudos sobre a Fenomenologia. Adotamos uma "postura fenomenológica".

De acordo com MASINI (1989), não existe o ou um método mas uma postura/atitude fenomenológica - a atitude de abertura (no sentido de estar livre de conceitos e definições apriorísticas) do ser humano para compreender o que se mostra, buscando remontar àquilo que está estabelecido como critério de certeza, assim questionando os seus fundamentos. Essa afirmação é corroborada por SANDERS (1982, p. 353) que atesta que "não existe nenhum procedimento ortodoxo que pode ser mantido e assegurado como o método fenomenológico" (COLTRO, 2000, p.38)

Em suma, procuramos descortinar as palavras dos alunos, buscando o seu sentido, os seus significados. Calmamente, refletimos sobre cada depoimento, na tentativa de ir além do "observável", materializado nas palavras dos alunos. Rojas, Fonseca e Souza (2010) defendem "que a pesquisa fenomenológica, ao partir da compreensão do nosso viver, e não de definições ou conceitos, desvenda o fenômeno além da aparência, na totalidade do mundo vivido."

Sadala (2004, p.8), descrevendo a pesquisa realizada com "alunas do $3^{\circ}$ ano da Faculdade de Enfermagem, que se encontravam desenvolvendo atividades de assistência a pacientes internados no isolamento", relata:

Durante as entrevistas procurei manter uma postura fenomenológica: apresentei-me, descrevi o meu trabalho, solicitei a sua colaboração, assim como a permissão para gravar. Nesse momento, expliqueiIhes que o projeto havia sido aprovado pela instituição, e obtive o seu consentimento formal. Busquei ouvilas de forma compreensiva e aberta, sem limite de tempo, envolvendo-me empaticamente, evidenciando o meu interesse. Sem interromper ou fazer outros questionamentos. Nesta abordagem, o sujeito da pesquisa se expressará espontaneamente a respeito dos significados da sua experiência. Os depoimentos foram posteriormente transcritos exatamente como foram expressos.

Forghieri (1993, p.62), em seu livro Psicologia Fenomenológica, relatando uma experiência de investigação sobre o tema "Contrariedade e bem-estar humanos", quanto à "Obtenção do Material de Estudo", orienta:

Um dos requisitos básicos da pesquisa fenomenológica diz respeito à maneira como é obtido o seu material de estudo, pois, devendo este ser constituído de relatos espontâneos e sinceros do sujeito sobre a sua vivência, alguns cuidados devem ser observados para que as informações por ele fornecidas sejam claras, autênticas e próximas de sua experiência imediata.

\section{REsULTADOS}

É notório que o perfil predominante do aluno evadido de cursos ofertados mais recentemente apresenta mudanças, se comparado ao perfil predominante observado nos primeiros cursos ofertados pelo IFB. Percebe-se, hoje, certa maturidade e traços de nível cultural e de escolaridade mais elevado e um direcionamento maior em suas escolhas. O número de pessoas que abandonaram o curso no IFB, superior ou técnico, por terem ingressado, simultaneamente, em curso superior em outra instituição, ou pelo fato de o cursarem concomitantemente e não conseguirem conciliar os dois, totaliza um grupo de 38 alunos, representando 17,43\% dos 218 alunos consultados. Não incluídos nesse grupo, 08 alunos declararam já ter um curso superior. Desses oito, 5 evadiram de curso superior do IFB, sendo que um deles abandonou para cursar o Mestrado, e 3, de curso técnico. Dentre os três últimos, 2 declararam já ter cursos de pós-graduação. As alegações de abandono também se apresentam mais concretas, menos fugidias, em sua maioria. Raramente demonstra ser aquele aluno que "caiu de paraquedas", porque o curso é gratuito. Naturalmente as críticas que tecem também ficam mais contundentes, como já o dissemos. Há mais assertividade na fala do aluno.

- Informante - Existem alguns pontos que deveriam ser avaliados pela Instituição de Ensino: o Conteúdo programático muito extenso do $2^{\circ}$ semestre para o curto período de aula, principalmente nas disciplinas $X$ e $Y$. Essas matérias deveriam ser dadas em dois semestres ou cada uma em um semestre, ou até mesmo o curso passar a ter 4 semestres, para melhor assimilação dos alunos. A metodologia utilizada para aplicação de uma disciplina em específico me deixou muito desestimulada, e não foi só eu que me senti assim, muitos e muitos alunos saem deprimidos do curso. É muita reprovação e desistência. Eu sinceramente não sei como o MEC ainda não investigou o motivo de tantas desistências e reprovações. Sinceramente, não queria ter desistido. Gostaria de poder ouvir falar que ocorreram algumas mudanças. Eu gostaria de poder voltar, gosto do IFB, a excelência no ensino é notória, um bom corpo docente, é uma pena que (...) possa afastar tanta gente assim. Muito obrigada pela oportunidade, não havia conseguido sequer ir até o Registro Acadêmico trancar a minha matrícula. Att. 
Um fato curioso e digno de nota é que, por meio da fala dos alunos, percebe-se que o perfil do IFB também está mais delineado. É como se essa fala permitisse entrever-se a identidade do IFB. Percebe-se que essa identidade está prestes a consolidar-se perante a sociedade. É muito provável que essa definição que hoje caracteriza o IFB seja responsável pelo perfil que ora se vê no aluno. Um perfil mais definido, mais compatível com as suas escolhas. Arriscaríamos dizer que à medida que o IFB se consolida, o aluno também se define.

Apesar dessa elevação flagrada no perfil do aluno, fica um ponto de interrogação: diante de tantas oportunidades de acesso aos estudos e, principalmente, em se tratando de curso superior gratuito e de qualidade, "por que ele se evade". Dados divulgados no site do IFB, no dia 13 de janeiro de 2014, nos mostram que a procura é muito grande.

Um total de 10.946 candidatos se inscreveram para concorrer às 83 vagas disponibilizadas pelo Instituto Federal de Brasília (IFB) nos quatro cursos de graduação por meio do Sistema de Seleção Unificada (Sisu), que considera o desempenho dos estudantes no Exame Nacional do Ensino Médio (Enem) para o ingresso em Instituições de Ensino Superior de todo o país.(...) Nesta edição do Sisu, o IFB apresentou uma concorrência geral de 131,9 candidatos por vaga. O curso mais concorridos foi o de Gestão Pública, ofertado pelo Campus Brasília, com 5.135 inscritos, uma concorrência de 223,3 candidatos para cada vaga oferecida. O curso de Licenciatura em Letras/Espanhol, do Campus Taguatinga Centro, recebeu 2.461 inscrições, relação de 123,05 candidato/vaga. Tecnologia em Agroecologia, oferecido pelo Campus Planaltina, e Licenciatura em Química, ofertado pelo Campus Gama, tiveram 1.704 e 1.646 inscritos, respectivamente, com 85,2 e 82,3 candidatos concorrendo para cada vaga ofertada. (www. ifb.edu.br)

Onde está a lacuna? Em conversa com alguns profissionais, há duas questões reiteradas com frequência, nem sempre hierarquizadas: a primeira ainda é a falta de informação sobre o curso e/ou interpretação equivocada sobre o que venha a ser o curso, não obstante a palestra orientativa já praticada pelo IFB; a segunda é a falta de conhecimentos prévios para o acompanhamento do curso. A respeito da primeira questão mencionada, Goiris et al (2012, p.183), em seu artigo intitulado "Influência da falta de informação na evasão escolar na percepção dos coordenadores de curso de graduação do CCHS/UFMS", trazem a informação de que

A falta de orientação vocacional é considerada um motivo de evasão em diversas universidades pesquisadas. Gaioso (2005) apresenta, em seu trabalho, diversas instituições em que os alunos evadidos apresentam a falta de orientação como causa de evasão. A Pontifícia Universidade Católica de Campinas (PUCCAMP), em duas ocasiões diferentes, apontou a falta de conhecimento sobre o curso e a profissão. Na Universidade Federal de São Carlos "a maioria dos desistentes sai por ter se decepcionado com o curso e pela a falta de orientação profissional no Ensino Médio" (GAIOSO, 2005, p. 18). Na Universidade de São Paulo (USP), a evasão ocorre pela escolha feita por candidatos prematuros e ausência de orientação vocacional no Ensino Fundamental. Na UFMT (Universidade Federal de Mato Grosso) o desconhecimento sobre o curso escolhido também é apontado como causa da evasão.

Na busca de causas plausíveis que justifiquem o paradoxo oportunidade versus evasão, há margem para a inferência de que o processo de inclusão ainda está por fazer.

Longe da defesa de que a responsabilidade pelo fracasso na escola cabe ao aluno, salvaguardando a parte de responsabilidade pessoal que the compete, constata-se que essa perversa apropriação - que não implica aqui a ideia de culpabilidade - está internalizada no próprio indivíduo, que se sente incluído ou não, que se sente parte daquele contexto ou não. Nele se efetiva a inclusão. Não estamos falando de responsabilização. Falamos, sim, de um indivíduo que assimilou e incorporou muito bem uma condição degradante de - "intransitivamente" - não participante. Trata-se de resultado colhido de um processo que só pode ser revertido por meio de políticas públicas operadas a médio e longo prazo. Em alguns casos, são questionáveis as alegações "problemas pessoais" e "não acompanhamento das aulas/turma por falta de conhecimentos". Flagra-se nessas declarações possíveis exemplos dessa perversa apropriação. É válido questionar em que nível essas causas são realmente de cunho pessoal e em que nível são consequências da ausência de suporte político-social, traduzidos em escolas de formação de qualidade.

É esse investimento, feito desde o início da infância, que diz ao indivíduo que ele pertence. E essa cultura não está impregnada em grande parte desse aluno que desiste. Somente o investimento de base, com seus frutos colhidos ao longo do tempo, poderá fazer com que, inclusive, as formas de ingresso hoje constituídas, materializadas como ferramentas de inclusão, garantam a permanência do aluno na escola. O aluno não se autossustenta no curso por muito tempo, se ele não tiver esse trabalho de base. Tudo indica que esse processo de inclusão começa lá atrás. A sua representatividade advém de uma escola de qualidade anterior a essas oportunidades. É isso que o sustenta na escola. Essas medidas inclusivas, por si só, não implicam a garantia da inclusão, porque não conseguem manter o aluno na escola. As portas se abrem, mas o aluno não consegue ficar. Havemos de convir que qualquer processo de instalação cultural é lento. É uma mudança de paradigmas. Se o aluno não tem uma base de qualidade, tampouco 
conseguirá usufruir de qualquer oportunidade que the seja oferecida. Não se sente parte. Não se sente capaz. Não se sente merecedor. E aí não age como tal. Não se vê naquele ambiente. Acostumado com reprovações constantes, o primeiro "não" é suficiente para expulsá-lo. Familiarizou-se com o fracasso escolar. A respeito desse preocupante quadro, Silva (2011) comenta:

No IFBA, a Evasão Escolar tem se transformado em um fenômeno presente e crescente. Em todos os conselhos acadêmicos diagnósticos, os profissionais da educação mencionam inúmeros casos de alunos com dificuldades, os quais apontam como solução a desistência da escola. (SILVA, 2011, p.1).

Mencionando o fracasso escolar como um dos problemas ocasionados pelo fenômeno da repetência no Brasil, Sousa et al (2011), em análise da evasão escolar de alunos que cursam o Ensino Médio regular em uma escola estadual da rede pública, no município de Maracanaú, Estado do Ceará, mencionam que

Outro fator impediente relacionado ao desinteresse dos jovens estudantes do Ensino Médio são as sucessivas reprovações, que têm significativo peso na decisão de continuar ou não os estudos, pois, geralmente, a repetência é seguida pelo abandono escolar (LOPEZ; MENEZES, 2002). O fenômeno da repetência no Brasil, que também ocorre no Ensino Fundamental, ocasiona outros problemas, dentre os quais a distorção idade-série (muitos alunos chegam ao Ensino Médio fora de faixa etária) e o fracasso escolar. (SOUZA et al, 2011, p.26)

Embora todas as formas de ingresso praticadas na atualidade sejam ferramentas no processo de consolidação de uma cultura da inclusão, as pesquisas nos têm mostrado que ainda não são esses mecanismos o ponto de resistência que impede a evasão do aluno, ou que o "segura", garantindo sua permanência na escola. O sustentáculo reside nele mesmo. Ele próprio se sente incluído ou não; ele próprio se inclui ou não. Trata-se do próprio sentimento de pertencimento, de valoração. Valoração de si mesmo. Valoração da escola. Valoração da oportunidade que lhe foi dada por esses instrumentos. E esse sentimento é construído ao longo dos bancos escolares, em escolas de formação de qualidade, frutos de políticas públicas claras, justas, sérias, não demagógicas. Arroyo (2000, p. 10), refletindo sobre "inquietações" a respeito da Educação Básica, assevera:

Recuperaremos o direito à Educação Básica universal para além de "toda criança na escola", se recuperarmos a centralidade das relações entre educadores e educandos, entre infância e pedagogos. Colocando seu ofício de mestre no centro da reflexão teórica e das políticas educativas. Colocando os conteúdos e os métodos, a gestão e a escola como mediadores desta relação pessoal e social. Como meios. Deixando de ver os professores (as) como recursos e recuperando sua condição de sujeitos da ação educativa junto com os educandos.

É isso o que lhe dá a certeza de fazer parte, de merecer aquele lugar. De valorizá-lo, inclusive. Nesse processo há o concurso da família, que traz, em seu seio, complexo legado sociocultural que potencializa o sentimento de pertencer ou o de não pertencer.

Oportunamente, colocamos em pauta outra reflexão sobre o processo de amadurecimento da cultura de inclusão - a abertura para a ampla concorrência, por meio de reserva de uma parcela de vagas e do preenchimento de vagas remanescentes, por desistência ou não, como forma de inclusão também nos cursos superiores. Nesse grupo também há carência de oportunidades. É o adulto afastado dos bancos escolares há tempos. É o adulto que, no primeiro obstáculo, não volta aos bancos escolares, por precisar priorizar outros compromissos, inclusive priorizar a vez dos filhos, em muitos casos. As dificuldades de acesso acabam por excluí-lo. Nem sempre consegue acompanhar os exames nacionais em pé de igualdade com os jovens. Enfrenta a muralha da tecnologia. O diálogo abaixo, embora ilustre um caso registrado no curso técnico, revela um pouco das dificuldades desse adulto que, por uma série de razões - questões financeiras, condições de se adaptar aos regulamentos vigentes, carência de orientação e suporte para se adequar ao contexto atual, dentre outras - fica excluído antes da largada.

- Informante - Naquele momento estava precisando muitíssimo ter uma renda e fui procurar um trabalho mas senti a discriminação pela idade embora forte, saudável e com disposição para o trabalho. Com a ajuda financeira de meu filho, consegui me aposentar com um salário e preciso continuar trabalhando como autônomo na construção civil. Tentei voltar e retomar o curso após a greve dos professores naquele ano que havíamos iniciado o primeiro semestre do curso mas não consegui. Lamentei e lamento não ter podido fazer parte do grupo que hoje está formado. Ainda tenho a esperança de voltar a estudar e fiz a minha reinscrição através da internet, mas não recebi a confirmação, não sei se ocorreu algum erro no sistema, o que justificaria a ausência de confirmação da inscrição. Gosto de estudar. (...) Pretendo continuar a minha caminhada por uma formação Tecnológica ou Técnica, (...)no intuito 
de conquistar uma melhor situação de trabalho e financeira. Muito Atenciosamente.

- Comunicante do IFB - Boa tarde, Senhor X. Obrigada pelo retorno. Estou encaminhando o seu e-mail à Coordenadoria de Registro Acadêmico do campus, que lhe dará as orientações necessárias. (...)

- Informante - Conforme vossa instrução de que eu poderia me inscrever no curso desejado a partir de 1/04/2014, e não estar conseguindo através do site do IFB/Samambaia-DF, SOLICITO VOSSO AUXÍLIO PARA ME INSCREVER EM EDIFICAÇÕES, através do Sorteio Eletrônico (...). Embora tenha meus dados como ex-aluno, posso reenviá-los se necessário. Agradeço muitíssimo se puder me ajudar. Atenciosamente.

- Comunicante do IFB - Boa tarde, Senhor X. Ficamos contentes em saber do seu interesse pelo curso Técnico em Edificações. O Edital foi publicado, porém as inscrições só acontecerão no período de $8 \mathrm{~h}$ do dia 7 de abril até às $18 \mathrm{~h}$ do dia 25 de abril. Por isso não conseguiu. As inscrições são totalmente online. No Processo Seletivo para os Cursos Técnicos Presenciais, não mais serão utilizadas as palestras presenciais. $E$ para completar a inscrição, o candidato deverá assistir à palestra por meio de vídeo online e preencher, ao término da apresentação, os códigos que foram exibidos no decorrer do vídeo. Somente depois disso é que haverá a confirmação da inscrição. Antes o candidato entrava no sistema para agendar e assistir à palestra no campus. Agora o vídeo já está disponibilizado no próprio sistema de inscrição. No vídeo aparecerão 03 códigos. O candidato deverá anotar e preencher os campos logo abaixo do vídeo. Dessa forma o candidato terá acesso para escolher o tipo de vaga e preencher o questionário socioeconômico e assim concluir sua inscrição. Estou enviandoIhe o edital. Estamos torcendo pelo seu retorno. Atenciosamente.

- Informante - Mais uma vez fico muitíssimo agradecido pela gentileza! Saúde e Paz!

Com certeza esse adulto que se encontra em fase de maturidade maior seria uma fatia que dificilmente evadiria e, melhor, contribuiria com essa nova ordem - a da inclusão. E, com certeza, influenciaria o outro grupo: o que evade.

Houve depoimentos bem claros sobre a falta de conhecimentos prévios para acompanhar o curso. Constatou-se uma menor escala dessa ocorrência, comparativamente à pesquisa anterior. Os alunos deixaram transparecer a consciência que tinham sobre essa carência. Por isso desistiram. Em casos específicos, os alunos foram orientados a fazer cursos FIC, no sentido de se prepararem para o curso técnico, cursando-o posteriormente. Situações dessa natureza nos deixam claro quão importante é o contato direto com alunos que se evadiram. Certamente um simples telefonema impede a quebra do vínculo entre esse aluno e a instituição. Mais sério ainda: vínculo entre esse aluno e a escola, o estudo, o ensino - a Educação.

- Informante 1 - "Esse curso para mim foi muito puxado, pois eu não tinha nenhuma noção de informática. Não conseguia acompanhar. Ai desisti."

- Informante 2 - Não me adaptei ao curso. (...)Não imaginava que o conteúdo fosse tão profundo quando escolhi o curso. Não conseguia acompanhar as aulas. Fiquei desestimulado. (...)

- Informante 3 - "Na época (..) não conseguia acompanhar porque não tinha alguns conhecimentos.

Alguns alunos não têm pressa de desligar o telefone. Transparecem refletir e delinear alguns caminhos profissionais e de trabalho enquanto fazem várias perguntas, buscando informações.

- Informante 1 - Estava animada com o curso, os professores eram maravilhosos e competentes, mas estava muito cansada. Trabalhava (...), não tinha tempo de preparar os trabalhos e não conseguia entregar e me preparar para os seminários. Chorei muito por precisar desistir.

Durante a conversa - ligação - abriu o site do IFB. Interessou-se pelos cursos de Samambaia. Fez várias perguntas em várias direções. Perguntou se há curso de Massoterapia. Sugeriu que a Instituição oferecesse. Atualmente está desempregada. Gostaria de ter uma qualificação rápida para trabalhar na área do curso. Agradeceu muito a ligação, que, segundo ela, serviu para lembrá-la dessa possibilidade e para incentivá-la.

Acentuadamente a questão do trabalho e tudo o que o envolve no dia a dia - horário coincidente com o do curso ou translado (trânsito caótico, transporte coletivo insuficiente e deficitário, distância) - monopolizam o rol de razões. Considerando que Brasília, geograficamente, é marcada por longas distâncias e que os centros culturais, centros de trabalho e de moradia se espalharam na capital 
federal, em especial na última década, sem contar com o contingente migratório que se concentra na Grande Brasília, destacaríamos o anseio de muitos alunos no tocante à ampliação de cursos de vários eixos tecnológicos nos diversos campi, o atendimento em diversos horários e a oferta do mesmo curso, concomitantemente, em mais de um campus, como forma de minimizar distâncias e problemas de horários de trabalho.

Em matéria publicada no site do IFB em 22 de agosto de 2013 referente à Audiência Pública realizada no Campus Gama no dia 21 de agosto de 2013, o depoimento da estudante N. R. ilustra bem esse anseio:

N. R. mora no Gama e estuda no Campus Brasília; a estudante frequenta o curso técnico em Serviços Públicos. Ela gostaria que o curso também pudesse ser oferecido na sua região. "Vejo que muitos colegas procuram esse curso lá na Asa Norte mas moram aqui", disse a aluna, ressaltando a dificuldade enfrentada com o transporte e com a distância do Campus Brasília desde a sua casa.

Essa expectativa também foi registrada nos depoimentos:

- Informante 1 - Fiquei muito triste, pois era o curso que sempre quis fazer. Trabalhei muito como cerimonialista de casamentos e debutantes, e com o curso eu iria me aprimorar. Agora para voltar ficou mais difícil, pois tenho me informado que o curso só está sendo ministrado pela manhã. Moro e trabalho em Brazlândia; para sair e voltar às 13 horas é inviável. Espero que no novo Campus da Ceilândia abra esse curso no turno da noite, assim ficará mais perto e mais viável pra mim.

Chama-nos a atenção o número de alegações em que subjazem causas circunstanciais de abandono e a insistente ocorrência de arrependimento pela desistência ou, simplesmente, o desejo de nova oportunidade. Após o contato feito, sempre nos vem a sensação de estar sendo instrumento de interferência na vida das pessoas, embora não tenhamos levantamento sobre quantos alunos retornaram após a nossa ligação ou e-mail.

- Informante 1 - Gostaria de ter uma nova oportunidade para retornar ao curso caso haja a possibilidade de uma nova inscrição pelo IFB.

- Informante 2 - Engravidei na época do curso. Não consegui conciliar. (...) Assim que eu desligar o telefone, vou entrar no site. Agradeço muito a sua ligação. Esse telefonema serviu de lembrete e incentivo para eu retornar aos estudos.
Catalogamos, oportunamente, sugestões de implantação de cursos, dentre outras pertinentes, a saber: Engenharias; Massoterapia; Francês; Cozinha (na ocasião da entrevista o curso estava em fase de aprovação - Campus Riacho Fundo); oferta do Curso Técnico em Manutenção e Suporte em Informática no período noturno (mais de uma pessoa sugeriu); cursos de curta duração (FIC) nas áreas de redes (cabeamento estruturado) e segurança da informação; oferta de cursos à noite (mais de uma pessoa sugeriu); Curso de Telecomunicações; Curso Técnico em Informática a distância, via web; ingresso no curso superior de outras formas, sem ser apenas pelo SISU; Curso de Dança à noite; Técnico em Eventos no Campus Ceilândia, à noite; Técnico em Eventos próximo de Taguatinga; Tecnologia de Segurança do Trabalho.

\section{CONSIDERAÇÕES PROPOSITIVAS}

A multiplicidade de atendimento do IFB e decorrências suscitam a necessidade de suporte contínuo ao professor, por meio de discussão permanente e estudos teóricopráticos que fundamentem as decisões em favor das demandas naturais desse processo.

Outrossim, a formação diversa que caracteriza o corpo docente do IFB, embora constitua realidade altamente positiva, pode representar ponto dificultador, se não observada com a devida atenção, considerando as modalidades de ensino oferecidas das quais os professores precisam dar conta e, ante o fato de, nem sempre, representarem a área de conforto do professor ingressante.

Essa diversidade que caracteriza o IFB tem exigido a inserção desses docentes no campo da pesquisa e extensão, como atores que determinarão o tom da qualidade do trabalho e dos serviços oferecidos. O plano de instituir Grupos de Estudos formados por docentes e técnicos fundamenta-se em experiências já desenvolvidas na Educação Profissional, a qual, por seu próprio caráter, acolhe professores com formação pedagógica diversa, atingindo casos de total isenção dessa formação. Entendemos que a implementação desses grupos em cada campus poderá ser o nascedouro de uma cultura de estudos pedagógicos a ser disseminada na instituição, cujos desdobramentos poderão ir além do que se espera, segundo a natureza de todo processo de estudo e formação. A "simulação de aulas" nas sessões de estudo, cujos temas poderão ser pertinentes ao Componente Curricular ou referentes a "hobbies" do professor, mediante a apreciação dos pares, que procederão a uma leitura da aula e à discussão sobre pareceres com o intuito de trazer à tona as abordagens de ensinoaprendizagem, é um caminho de união e descontração do grupo, o qual, natural e gradativamente, se envolve 
no delicado processo de autoavaliação e avaliação de sua prática docente perante o grupo.

O objeto de observação pode ser o mesmo, mas as reflexões que este suscita são ímpares, contextuais com a experiência de cada observador. Cada um terá um foco de atenção sobre o qual refletirá. Nos focos diferenciados e até divergentes de cada observador surge a reflexão conjunta. E é nessa reflexão conjunta que desencadeia a teorização da prática. A partir daí a teoria faz sentido, explicando impasses vividos na docência. Com ela concordamos, discordamos e, a partir dela, criamos outras. (FREDENHAGEM, 2002, p. 187)

A naturalidade de se tratar com o "eu não sei" e/ ou "preciso aprender" é um dos grandes ganhos da descontração que se vai construindo na sequência dos encontros. Por isso a sugestão de apresentação de "hobbies" como objeto da aula, no lugar de conteúdo do componente curricular ministrado pelo professor. $\mathrm{O}$ "hobby", como objeto da aula, seria uma ferramenta de descontração para os primeiros encontros, considerando que tira de foco a figura do professor. Aos poucos o grupo vai se afinando. Os "erros" tornam-se, muitas vezes, motivos de risos, e não de constrangimento. Preparar o grupo para futuras observações "in loco", em aulas reais, compartilhando o ambiente com os pares, por meio da convivência nos encontros e das "simulações", objetivando consolidar a teorização da prática, torna-se, consequentemente, passo natural, visto como ajuda mútua, e não como intromissão. É tarefa cultivada.

Percebemos que é possível ajudar o professor a buscar os significados da sua prática docente, a partir da análise e do estudo dessas situações de ensino oriundas de sua própria atuação em sala de aula. Ter clareza quanto ao significado de cada ato na docência e a que rumos estes levam representa, sobretudo, exercitar princípios de respeito ao ser humano de cuja formação o professor participa. (FREDENHAGEM, 2002, p. 186)

Retomando o foco deste artigo, diríamos que problemas causadores de evasão e insucesso do aluno poderiam ser minimizados, resolvidas carências didático-pedagógicas, que se tornam questões, na sua maioria, de ordem interna da Instituição. A presença dos segmentos docente e técnico nesses grupos de estudo formados em cada campus facilitaria intervenções locais, em tempo real, em favor de reverter a decisão do aluno de evadir-se.

\section{Conclusões}

Do assistencialismo e da filantropia - não raro ancorados no preconceito e na subalternidade - ao empreendedorismo e seus pressupostos atributos, identidade assumida a partir das duas últimas décadas, a Educação Profissional no Brasil ganha, hoje, outras dimensões, tendo em vista o papel estratégico que toma para si, mediante, de um lado, as exigências de competitividade e desenvolvimento humano sob a égide da complexa reorganização socioeconômica, imposta pelas novas tecnologias e relações internacionais, de outro, o fenômeno da convivência entre reafirmações e negações ante o impasse do que venha a ser, de fato, desenvolvimento e inclusão. Assume, assim, novo contorno.

A Lei $n^{\circ} 11.892$, de 29 de dezembro de 2008, que instituiu a Rede Federal de Educação Profissional, Científica e Tecnológica, criando o Instituto Federal de Educação, Ciência e Tecnologia de Brasília, vem contribuir para clarificar esse impasse. Cabe lembrar que os Institutos Federais são instituições de educação superior, básica e profissional, pluricurriculares e multicampi, especializados na oferta de educação profissional e tecnológica nas diferentes modalidades de ensino, com base na conjugação de conhecimentos técnicos e tecnológicos com as suas práticas pedagógicas, nos termos desta Lei, conforme reza o seu artigo segundo. A diversificação de ofertas, prevista e garantida legalmente, concorre para aumentar as chances de atendimento social, considerando questões geográficas e socioeconômicas a que estudantes estão sujeitos.

$\mathrm{O}$ artigo mencionado no parágrafo anterior resume e consolida os anseios expressos no documento intitulado "Manifestação do Concefet sobre os Institutos Federais de Educação, Ciência e Tecnologia" (2007), que é o registro do resultado das discussões, no âmbito do Conselho de Dirigentes dos Centros Federais de Educação - Concefet, a respeito da proposta de criação dos Institutos Federais, os quais, conforme apresentação do documento, podem melhor "traduzir o significado da educação profissional e tecnológica enquanto modalidade potencializadora do indivíduo no desenvolvimento de sua capacidade de gerar conhecimento a partir de uma prática interativa com a realidade".

Nessa perspectiva, a presente pesquisa sobre Evasão Escolar constitui-se como instrumento de garantia de verificação das necessidades de atendimento em favor da inclusão, bem como torna-se ponto estratégico de acompanhamento, na perspectiva da meta-avaliação, como autocrítica da Instituição, de forma a contribuir com ações interventivas em favor do esperado desenvolvimento. 
Conforme nos mostram as bibliografias consultadas, é importante que se diga que o fenômeno "evasão" é único em todo o país, em todas as instâncias, mas suas causas nem sempre. A diversidade também se faz aí presente. A exemplo, embora "trabalho" monopolize os números, cada região merece atenção especial, por meio de olhar atento, pois o mesmo tema apresenta faces diferentes em cada contexto, exigindo medidas diferentes, portanto.

\section{REFERÊNCIAS}

AJALA, M.C. Aluno EJA: motivos de abandono e retorno escolar na modalidade EJA e expectativas pós EJA em Santa Helena-PR. Monografia de Especialização. Universidade Tecnológica Federal do Paraná, 2012. Disponível em: http://repositorio.roca.utfpr.edu.br/jspui/ bitstream/1/1647/1/MD_PROEJA_2012_IV_16.pdf. Acesso em 26 de abril de 2014.

ARROYO, M.G. Ofício de mestre. Petrópolis, RJ: Editora Vozes, 2000.

ASCÊNCIO, R. F. R. O significado que os pais atribuem à obesidade de seus filhos. Dissertação (Mestrado). Faculdade de Psicologia da Universidade São Marcos. São Paulo, 1998.

BRASIL. Lei n 11.892, de 29 de dezembro de 2008. Institui a Rede Federal de Educação Profissional, Científica e Tecnológica, cria os Institutos Federais de Educação, Ciência e Tecnologia, e dá outras providências. Diário Oficial da República Federativa do Brasil, Brasília, DF, 30 dez. 2008. Seção 1, p.1.

COLTRO, A. A fenomenologia: um enfoque metodológico para além da Modernidade. Caderno de Pesquisas em Administração, 2000. São Paulo, Vol.1 (11), p.38. Disponível em: http://www.regeusp.com.br/arquivos/C11 art05.pdf. Acesso em 25 out. de 2014.

CONCEFET. Manifestação do Concefet sobre os Institutos Federais de Educação, Ciência e Tecnologia: documento. Revista Brasileira da Educação Profissional e Tecnológica, v. 1, n. 1, 2008.

ESTADOS do nordeste lideram em abandono escolar no ensino médio.http://portal.aprendiz.uol.com. br/2011/07/11/estados-do-nordeste-lideram-emabandono-escolar-no-ensino-medio. Fonte: Folha de São Paulo. Acesso em 21 de maio de 2014.

FORGHIERI, Y. C. Psicologia fenomenológica. São Paulo, Pioneira, 1993.

FREDENHAGEM, S. V.; COMETTI, N. N.; BONFIM, C. J. de L.; ARAÚJO, F. D. de. A voz da evasão. Revista Eixo, v.1, n.2. Brasília: Instituto Federal de Brasília, 2012.

FREDENHAGEM, S. V. A observação da sala de aula: uma perspectiva. In VALE, JÚNIOR, LUCCI, MAGNONI (Org.). Escola pública e sociedade. Bauru: Atual, AGB, Saraiva, pp. 185-193, 2002.

—_ Capacitação Didático-Pedagógica: habilidades de ensino do professor. Revista Synthesis, n 5, pp.8693. São Paulo: Centro Estadual de Educação Tecnológica Paula Souza, 1998.

Capacitação Didático-Pedagógica: O Conselho de Classe a partir de uma prática reflexiva e do Estudo de Casos. Seminário A Nova Educação Profissional. Livro de resumos. São Paulo: Centro Estadual de Educação Tecnológica Paula Souza, 2000.

GOIRIS, M. C.; REINERT, J. N.; GUBIOTTI, B. Influência da falta de informação na evasão escolar na percepção dos coordenadores de curso de graduação do CCHSI UFMS. Iniciação Científica Cesumar, jul./dez. 2012, v.14, n. 2, p.179-189. Disponível em: http://www.cesumar. br/pesquisa/periodicos/index.php/iccesumar/article/ download/2347/1776. www.scholar.google.com.br. Acesso em 26 de abril de 2014.

GÓMEZ, A.P. O pensamento prático do professor: a formação do professor como profissional reflexivo. In NÓVOA, António (Org.). Os professores e a sua formação. Lisboa: Publicações Dom Quixote - Instituto de Inovação Educacional, pp.93-114, 1997.

GREGO, S. M. D. A avaliação institucional dos cursos de graduação. A meta-avaliação como referencial de análise e de reflexão. in SGUISSARDI, V. (Org). Avaliação universitária em questão. Campinas: Editora Autores Associados, 1997. p.91-116. 
IBGE. http://noticias.terra.com.br/educacao/ibgeabandono-escolar-no-brasil-e-3-vezes-maior-que-na-eur opa,9608febb0345b310VgnCLD200000bbcceb0aRCRD. html 28 de Novembro de 2012. Fonte: IBGE. Acesso em 22 de março de 2014.

INDICE de evasão escolar é maior entre estudantes do ensino médio.http://redeglobo.globo.com/ globoeducacao/noticia/2011/10/indice-de-evasao-escolare-maior-entre-estudantes-do-ensino-medio.html. Acesso em 21 de maio de 2014.

KLEIN, C. R.; FREITAS, M. do C. D. Motivos do abandono escolar na educação de jovens e adultos: estudo de caso escola do Paraná. Disponível em: http://www.esocite.org. br/eventos/tecsoc2011/cd-anais/arquivos/pdfs/artigos/ gt007-motivosdo.pdf. Acesso em 26 de abril de 2014.

LUDKE, M.; ANDRÉ, M. Pesquisa em educação: abordagens qualitativas. São Paulo: EPU, 1986.

MOREIRA, M. A. e MASINI, E. F. S. Aprendizagem significativa. A teoria de David Ausubel. São Paulo: Editora Moraes Ltda, 1982.

ROJAS, J.; FONSECA, R. B. e SOUZA, R. S. Fenomenologia e rigor na pesquisa educacional: a experiência da UFMS. IV SIPEQ - ISBN - 978-85-98623-04-7, 2010. Anais... Rio Claro: IV SIPEQ, 2010. Disponível em: http://www.sepq. org.br/IVsipeq/anais/index.html. Acesso em 27 de out. de 2014.

SADALA, M. L. A. A Fenomenologia como método para investigar a experiência vivida uma perspectiva do pensamento de Husserl e de Merleau Ponty. Botucatu. UNESP, 2004. Disponível em: http://www.sepq.org.br/ Ilsipeq/anais/pdf/gt1/12.pdf. Acesso em 25 de out. de 2014.

SANT'ANNA, F. M. Microensino e habilidades técnicas do professor. Porto Alegre: Bels, 1974.

SILVA, W. F. Evasão escolar nos cursos técnicos integrados do IFBA Campus Eunápolis. ANPAE, 2011. Anais... São Paulo: Anpae, 2011. Disponível em: http:// www.anpae.org.br/simposio2011/cdrom2011/PDFs/ trabalhosCompletos/comunicacoesRelatos/0548.pdf. Acesso em: 19 set 2013.

SOBRINHO, J. D. Avaliação quantitativa, avaliação qualitativa. interações e ênfases. In: SGUISSARDI, V. (Org).
Avaliação universitária em questão. Campinas: Editora Autores Associados, 1997. p.71-87.

SOUSA, A. de A.; SOUSA, T. P. de; QUEIROZ, M. P. de; SILVA, E. S. L. da. Evasão escolar no ensino médio: velhos ou novos dilemas? Vértices, 2011, Vol.13(1), p.25. Disponível em: http://www.periodicos.capes.gov.br/. http://essentiaeditora.iff.edu.br/index.php/vertices/article/ viewArticle/1220. Acesso em: 26 de abril de 2014.

SOUZA, S. C. A. de. A evasão discente na educação superior e a relação com as políticas públicas de ingresso. IX Colóquio de Pesquisa Sobre Instituições Escolares - História e Atualidade do Manifesto dos Pioneiros da Educação Nova, 2013. Anais... São Paulo, 2013. Disponível em: http://www.uninove.br/marketing/ix coloquio/trabalhos_completos.html. Acesso em: 19 set 2013.

Recebido em: 06/06/2014

Aceito em: 03/11/2014 